\title{
Revisão das espécies de Melanosmicra Ashmead (Hymenoptera, Chalcididae)
}

\author{
Andrea Barbieri Navarro-Tavares ${ }^{1} \&$ Marcelo Teixeira Tavares ${ }^{2}$
}

${ }^{1}$ Programa de Pós-graduação em Ciências Biológicas (Zoologia), Universidade Federal do Espírito Santo, Avenida Marechal Campos 1468, 20.043-900, Vitória-ES, Brasil. abnavarro30@gmail.com.br

${ }^{2}$ Departamento de Ciências Biológicas, Universidade Federal do Espírito Santo, Avenida Marechal Campos 1468, 20.043-900, Vitória-ES, Brasil. tavares.mt@gmail.com

\begin{abstract}
Revision of species of Melanosmicra Ashmead (Hymenoptera, Chalcididae). Thirteen species are treated, four are redescribed: Melanosmicra areta (Burks, 1939), M. flavicollis (Cameron, 1904), M. gracilis (Kirky, 1889) and M. immaculata Ashmead, 1904. Melanosmicra variventris (Cameron, 1913) is proposed as a new junior synonym of $M$. immaculata. Nine new species are described: $M$. acutodentata sp. nov., $M$. bilobata sp. nov., $M$. carenata sp. nov., $M$. guara sp. nov., M. latidentata sp. nov., M. nigra sp. nov., M. polita sp. nov., M. rugosa sp. nov. and $M$. tricolor $\mathbf{s p .}$ nov.. A key and illustration are presented for males and females.
\end{abstract}

KEYWORDS. Chalcidini; Neotropical; new species; parasitic wasps; taxonomy.

RESUMO. Revisão das espécies de Melanosmicra Ashmead (Hymenoptera, Chalcididae). São tratadas treze espécies, das quais quatro redescritas: Melanosmicra areta (Burks, 1939), M. flavicollis (Cameron, 1904), M. gracilis (Kirby, 1889) e M. immaculata Ashmead, 1904. Melanosmicra variventris (Cameron, 1913) é proposta como sinônimo júnior de $M$. immaculata. São descritas nove espécies novas: M. acutodentata sp. nov., M. bilobata sp. nov., M. carenata sp. nov.,

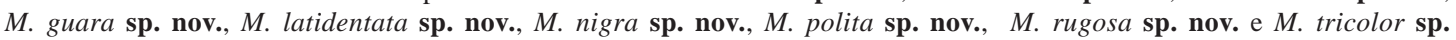
nov.. São apresentadas chave de identificação e ilustrações para as espécies.

PALAVRAS-CHAVE. Chalcidini; espécies novas; Neotropical; parasitóides; taxonomia.

Melanosmicra foi descrito por Ashmead (1904) que designou M. immaculata Ashmead, 1904 como espécie-tipo. Poucos meses após, Cameron (1904) descreveu Platychalcis e designou como espécie tipo P. flavicollis Cameron, 1904. Burks (1940) considerou Melanosmicra sinônimo júnior de Ceratosmicra Ashmead, 1904 com base no comprimento do pecíolo das espécies.

Delvare (1992), em sua revisão dos gêneros de Chalcidini do Novo Mundo, revalidou Melanosmicra por considerar o comprimento do pecíolo um caráter homoplásico e propôs Platychalcis como seu sinônimo júnior. Aquele autor propôs, também a divisão do gênero em dois grupos de espécies: immaculata, composto por M. immaculata, M. areta (Burks, 1939), M. gracillis (Kirby, 1889), M. variventris (Cameron, 1913) e ao menos, 20 outras espécies não descritas; e flavicollis, composto por M. flavicollis (Cameron, 1904) e outra espécie não descrita.

Exceto por M. flavicollis, que também ocorre nos Estados Unidos, as demais espécies conhecidas são exclusivamente neotropicais e não há registros sobre os hospedeiros das espécies deste gênero (Noyes, 2002).

Embora Delvare (1992) tenha proposto um melhor delineamento para Melanosmicra, pouco foi feito para o reconhecimento de suas espécies.

No presente estudo são apresentadas revisão, redescrição das espécies e descrição de espécies novas.

\section{MATERIAL E MÉTODOS}

O material estudado é proveniente das seguintes coleções: BMNH, The Natural History Museum, Londres, Reino Unido; CAS, Califórnia Academy of Sciences, São Francisco, EUA; DCBU, Departamento de Ciências Biológicas, Universidade Federal de São Carlos, São Carlos, Brasil; DCMB, Laboratório de Zoologia, Departamento de Ciências Morfológicas, Fundação Universidade do Amazonas, Manaus, Brasil; DZUP, Coleção de Entomologia Pe. Jesus Santiago Moure, Universidade Federal do Paraná, Curitiba, Brasil, EMEC, Essig Museum of Entomology, Departament of Entomological Sciences, University of California, Berkeley, EUA; FIOC, Fundação Instituto Oswaldo Cruz, Rio de Janeiro, Brasil; IBSP, Coleção Entomológica "Adolph Hempel” do Instituto Biológico, São Paulo, Brasil; IBGE, Coleção Zoológica da Reserva Ecológica do Instituto Brasileiro de Geografia e Estatística, Brasília, Brasil; INPA, Coleção Sistemática de Entomologia, Instituto Nacional de Pesquisas da Amazônia, Manaus, Brasil; MNRJ, Museu Nacional do Rio de Janeiro, Universidade do Rio de Janeiro, Rio de Janeiro, Brasil; MPEG Departamento de Entomologia, Museu Paraense Emílio Goeldi, Belém, Brasil; MZSP, Museu de Zoologia da Universidade de São Paulo, São Paulo, Brasil; QCAZ, Catholic Zoology Museum, Pontificia Universidad Catolica del Ecuador, Quito, Equador; UFES, Coleção do Departamento de Ciências 
Biológicas, Universidade Federal do Espírito Santo, Vitória, Brasil; UFMG, Universidade Federal de Minas Gerais, Departamento de Zoologia, Belo Horizonte, Brasil.

Os termos morfológicos seguem principalmente Gibson (1997), os específicos para Chalcidini seguem Delvare (1992) e a terminologia escultural segue Harris (1979), exceto para o termo umbilicado (Bouček, 1988).

Foram tomadas medidas de acordo com Delvare (1992), exceto quando indicado de outra forma, e as seguintes acronímias foram utilizadas: A, altura; AO, altura do olho; APL, distância entre o ocelo anterior e posterior; $\mathrm{C}$, comprimento; CTE (espaço torulo-clipeal), distância máxima entre a margem inferior do soquete antenal e a margem do clípeo; DOA, maior diâmetro do ocelo anterior; EM (espaço malar), distância entre a margem ocular e a margem oral; EPE, largura do espaço paraescrobal na mesma altura em que foi medida a largura do escrobo; ES, comprimento da nervura estigmal; F, funículo antenal (exemplo: F1 primeiro; F2 segundo...); FO, distância entre os dois ângulos da fossa oral; FV (frontovértice), distância entre as margens oculares na linha da margem anterior do ocelo anterior; L, largura; LF, largura em vista frontal; LS, maior largura do escrobo; $\mathrm{M}$, comprimento da nervura marginal; OOL, menor distância entre o ocelo posterior e o olho; PM, comprimento máximo da nervura pós-marginal; POL, distância entre os ocelos posteriores; SM, comprimento da nervura submarginal; $\mathrm{T}$, tergito do gáster (exemplo: T1 primeiro; T2 segundo...).

Nos itens Distribuição, os países (ou estados, no caso do Brasil) citados pela primeira vez são marcados com asterisco (*).

Chave de identificação para machos e fêmeas de Melanosmicra

1. Macho .2

Fêmea 8

2(1). Mandíbula 2.2, dente inferior mais longo que o superior; mesonoto com umbílicos esparsos, interstício liso e brilhante (Fig. 23); projeção interantenal indicada por carena inconspícua (Fig. 27) (grupo flavicollis); cabeça mais larga que alta; escapo nunca ultrapassa a margem anterior do ocelo anterior; propódeo com carena mediana bem definida na junção com cóstula anterior (Fig. 23); metafêmur com dente basal externo curto, largo e arredondado no ápice, o interno curto, triangular com ápice agudo M. flavicollis

Mandíbula 2.3 ou 3.3 (Fig. 67), dente superior mais longo que o inferior; mesonoto com umbílicos próximos, interstício coriáceo (Figs. 21 e 36); projeção interantenal indicada ao menos por uma carena conspícua (Figs. 5, 18, 30, 35, 40, 44, 47, 55 e 62); demais caracteres variáveis (grupo immaculata) .... 3

3(2’). Projeção interantenal pouco proeminente, com carena no topo (Fig. 55); metafêmur com dentes externos pequenos e muito justapostos, o basal externo pouco desenvolvido e arredondado (Fig. 59)

M. rugosa sp. nov.

Projeção interantenal proeminente (Figs. 18 e 30); metafêmur com dentes externos mais espaçados, usualmente maiores, o basal externo mais desenvolvido e agudo (Figs. 8, 20, 34, 50 e 68) ........ 4

4(3'). Metafêmur com dente basal externo triangular laminar (Fig. 68) M. tricolor sp. nov.

Metafêmur com dente externo triangular não laminar (Figs. 8, 20, 34 e 50) 5

5(4'). Projeção interantenal muito proeminente, triangular em vista frontal e arredondada acima (Fig. 18); propódeo com carena transversal completa entre as cóstula anterior e posterior (Fig. 21); metafêmur com margem anterior ligeiramente arqueada e 18 dentes ventrais (Fig. 20) . M. bilobata sp. nov.

Projeção interantenal proeminente e comprimida lateralmente (Fig. 40); propódeo sem carena transversal entre as cóstulas anterior e posterior (Figs. 2 e 49); metafêmur com margem anterior reta (Figs. 8, 34 e 50) e no máximo 15 dentes ventrais

6(5’). Espaço paraescrobal com área inferior ligeiramente proeminente (Fig. 30); face inferior com porção mediana pouco saliente, quase plana (Fig. 30); metatíbia marrom-clara ou escura, com mancha amarela próxima ao ápice; gáster marrom-avermelhado ......... M. gracillis

Espaço paraescrobal com área inferior não proeminente (Figs. 5 e 47); face inferior com porção mediana convexa, saliente (Figs. 5 e 47); metatíbia preta ou marrom com mancha amarela próxima ao ápice; gáster marrom-escuro ou mesclado de amarelo e marrom ... 7

7(6'). Escapo com 3/4 apicais dilatados, que ultrapassa a margem anterior do ocelo anterior por $0,25 \mathrm{x}$ o seu comprimento; metacoxa delgada (Fig. 8); metafêmur com dente basal externo de tamanho igual ao segundo (Fig. 8), dente basal interno ausente (Fig. 9) ou, se presente, curto, triangular e com ápice agudo; metatíbia com espinho apical delgado (Fig. 9) ......... .. M. acutodentata $\mathbf{s p . ~ n o v . ~}$

Escapo não dilatado no ápice, que ultrapassa a margem anterior do ocelo anterior por $0,5 \mathrm{x}$ o seu comprimento; metacoxa robusta; metafêmur com dente basal externo maior que o segundo (Fig. 50), dente basal interno mais desenvolvido, triangular com ápice rômbico; metatíbia com espinho apical robusto (Fig. 50) ........ M. nigra sp. nov.

8(1').Mandíbula 2.2, dente inferior mais longo que o superior; mesonoto com umbílicos esparsos, interstício liso e brilhante (Fig. 23); projeção interantenal indicada 
por carena inconspícua (Fig. 27) (grupo flavicollis); cabeça mais larga que alta; escapo nunca ultrapassa a margem anterior do ocelo anterior; propódeo com carena mediana bem definida na junção com a cóstula anterior; carena frenal ausente

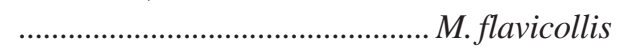

Mandíbula 2.3, dente superior mais longo que o inferior; mesonoto com umbílicos próximos (Fig. 41), interstício coriáceo; projeção interantenal indicada ao menos por uma carena conspícua; demais caracteres variáveis (grupo immaculata) .... ... 9

9(8'). Metafêmur sem dente interno, o basal externo diminuto (Fig. 15), margem anterior arredondada; hipopígeo com ápice bilobado (Fig. 17); projeção interantenal muito proeminente, triangular em vista frontal e arredondada acima (Fig. 18); covas tentoriais profundas e conspícuas (Fig. 18); espinho apical da metatíbia reto (Fig. 20) .............. M. bilobata sp. nov.

Metafêmur com dente interno presente, margem anterior reta (Figs. 43, 50 e 65); hipopígeo com ápice arredondado ou angulado; demais caracteres, se presentes, não ocorrendo em conjunto 10

10(9'). Metafêmur com dente basal interno falciforme (Figs. 51 e 66) 11

Metafêmur com dente basal interno triangular (Fig. 39 e 70), trapezoidal (Fig. 60) ou em formato de quilha (Fig. 46) .. 16

11(10). Metafêmur estreitado na base (Figs. 43 e 50); metapleura umbilicado-foveada ou com fóveas somente na metade ou quarto inferior; metatíbia com espinho apical mais robusto e recurvado (Figs. 38, 43, 50 e 65); gáster marrom ou avermelhado ......... 12 Metafêmur não estreitado na base (Fig. 3), demais caracteres não ocorrendo em conjunto 15

12(11). Dente basal externo do metafêmur sem lâmina anterior (Fig. 50); metapleura muito pilosa, com fóveas apenas no quarto inferior (Fig. 48); carena frenal arredondada, raramente em formato de " $\mathrm{V}$ "

M. nigra sp. nov.

Dente basal externo do metafêmur com lâmina anterior recurvada (Figs. 38, 43 e 65); metapleura umbilicadofoveada ao menos na metade inferior; carena frenal com formato de "V" (Figs. 41 e 64) .. 13

13(12').Metapleura umbilicado-foveada, exceto por pequena área inferior (Fig. 37); dorso do mesoescuto e escutelo densamente umbilicados, umbílicos profundos e interstício fortemente coriáceo; projeção interantenal proeminente, com base não espessa e perfil anguloso no dorso; propódeo com área submediana rugosa (Fig. 36); porção inferior da lateral do pronoto com duas carenas oblíquas (Fig. 37) .... M. guara sp. nov.
Metapleura sem fóveas na metade superior (Fig. 42); dorso do mesoescuto e escutelo não densamente umbilicados, umbílicos menos profundos (Fig. 41) e interstício coriáceo; projeção interantenal com perfil arredondado; propódeo com área submediana coriácea (Figs. 41 e 64) ou coriáceo-rugosa; porção inferior da lateral do pronoto com carena oblíqua (Fig. 42) .. 14

14(13'). Sulco malar profundo, carena interna completa; projeção interantenal proeminente com base mais espessa, ligeiramente projetada para frente com perfil arredondado (Fig. 40); escapo ultrapassa a margem anterior do ocelo anterior por $0,5 \mathrm{x}$ o seu comprimento; metade superior da metapleura com pontuação delicada e a inferior umbilicado-foveada, exceto por pequena área inferior coriácea (Fig. 42); metafêmur avermelhado, com dente basal externo mais longo que os demais (Fig. 43); gáster avermelhado .........

M. immaculata

Sulco malar raso, carena interna interrompida medianamente; projeção interantenal com base menos espessa e não projetada para frente (Fig. 62); escapo ultrapassa a margem anterior do ocelo anterior por $0,2 \mathrm{x}$ o seu comprimento; metapleura pilosa, com pontuação delicada, exceto área mediana umbilicadofoveada; metafêmur com face externa negra e faixa mediana transversal amarela, dente basal externo de tamanho semelhante aos demais (Fig. 65); gáster marrom-claro M. tricolor sp. nov.

15(11'). Dente basal externo do metafêmur arredondado (Fig. 11); metatíbia com espinho apical robusto e pouco curvado (Fig. 11); metapleura com pontos pilíferos pequenos na área superior e central, área inferior umbilicado-foveada; gáster marrom ou marrom avermelhado .................................................... . areta Metafêmur com dente basal externo triangular agudo (Fig. 3); metatíbia com espinho apical não tão robusto e curvado (Fig. 3); metapleura com faixa mediana foveada, área superior com fóveas pouco delimitadas, a inferior lisa e brilhante; gáster manchado de amarelo e marrom

M. acutodentata $\mathbf{s p . ~ n o v . ~}$

16(10'). Projeção interantenal pouco proeminente com carena no topo (Fig. 55); lateral do pronoto fracamente rugosa (Fig 58); interstício do mesossoma fracamente coriáceo ... 17

Projeção interantenal muito proeminente, espessa ou lateralmente comprimida em lâmina estreita (Figs. 40, 47 e 62 ou como na Fig. 44); lateral do pronoto rugosa (Figs. 37 e 48); interstício do mesossoma conspicuamente coriáceo .. 18

17(16). Face inferior com interstício conspicuamente coriáceo 
(Fig. 55); mesoescuto e escutelo castanho-claros; metafêmur com dentes externos pequenos e muito justapostos, o externo basal pouco desenvolvido e arredondado (Fig. 59); o interno basal trapezoidal (Fig. 60) ou triangular curto .......... M. rugosa sp. nov. Face inferior com interstício fracamente coriáceo, quase liso; mesoescuto e escutelo manchados de amarelo e marrom; metafêmur com dentes ventrais de tamanhos variados e espaçados, o externo basal o maior, triangular e com lâmina recurvada anteriormente (Fig. 70), o interno basal triangular e longo (Fig. 71). M. carenata $\mathbf{s p . ~ n o v . ~}$

18(16'). Metapleura umbilicado-foveada, exceto por pequena área inferior coriácea (Fig. 37); propódeo com área submediana rugosa (Fig. 36); metafêmur com dente basal externo distintamente menor que o maior dente ventral (Fig. 38) M. guara sp. nov.

Metapleura na metade superior com pontos pilíferos pequenos, metade inferior umbilicado-foveada; propódeo com área submediana coriácea (Fig. 10, 45), coriáceo-rugosa ou fracamente coriácea (Fig. 52); metafêmur com dente basal externo distintamente maior ou igual aos demais ventrais (Figs. 11, 46 e 53)

19(18'). Escapo apicalmente alargado (como na Fig. 13), ultrapassa a margem anterior do ocelo anterior por 0,5x o seu comprimento; projeção interantenal muito proeminente, triangular em vista frontal e arredondada acima (como na Fig. 18); metafêmur com dente basal interno pouco desenvolvido (Fig. 54); mesoescuto e escutelo amarelos, umbílicos rasos (Fig. 52); propódeo com área submediana brilhante e inconspicuamente coriácea, carena mediana fraca anteriormente (Fig. 52) .... M. polita sp. nov.

Escapo apicalmente não alargado (como nas Figs. 56 e 63), ultrapassa a margem anterior do ocelo anterior por, no máximo, $0,25 x$ o seu comprimento; projeção interantenal lateralmente comprimida (como na Fig. 47) ou afilada no topo (Fig. 44); metafêmur com dente interno basal bastante desenvolvido (Figs. 12 e 46); mesoescuto e escutelo pretos, umbílicos profundos; propódeo com área submediana coriácea (Figs. 10 e 45) ou coriácea-rugosa, carena mediana bem definida em toda sua extensão (Figs. 10 e 45) 20

20(19'). Metafêmur com 12 dentes ventrais externos, os basais, externo e interno, em forma de quilha (Fig. 46); projeção interantenal proeminente, com perfil anguloso e ligeiramente projetada para frente (Fig. 44); metatíbia com espinho apical longo (Fig. 46); gáster manchado de amarelo e marrom ....

M. latidentata sp. nov.

Metafêmur com 14 dentes ventrais externos, o basal laminar (Fig. 11), dente basal interno triangular (Fig.
12), trapezoidal ou ligeiramente falciforme, ocasionalmente com um ou dois dentes menores associados; projeção interantenal proeminente, com base mais espessa e perfil arredondado; metatíbia com espinho apical não tão longo (Fig. 11); gáster marrom-escuro ou marrom-avermelhado .... M. areta

\section{Melanosmicra acutodentata $\mathbf{s p . ~ n o v . ~}$}

(Figs. 1-9)

Etimologia. O epíteto específico refere-se ao dente basal externo do metafêmur ponteagudo.

Descrição. Fêmea. Comprimento: 3,8-5,5mm (holótipo: 4,2mm).

Coloração. Frontovértice, face inferior, escrobo, parte da área paraescrobal, mesoescuto e escutelo, meso e metapleura, mancha na lateral externa da metacoxa, base e ápice do metafêmur, base e ápice da metatíbia, ápice dos tarsos posteriores e dentes ventrais do metafêmur pretos; escapo, projeção interantenal, mancha na área paraescrobal, labro, clípeo, dentes mandibulares, tégula, perna anterior e média, metacoxa (exceto área lateral externa) e pecíolo amarelos. Flagelômeros antenais marrons. Gáster mesclado de amarelo e marrom. Asas hialinas, nervuras castanho-claras.

Cabeça. Pilosidade densa no frontovértice e face superior e inferior. Superfície com umbílicos irregulares e rasos; interstício coriáceo, também no escrobo (Fig. 5). Projeção interantenal proeminente, lateralmente comprimida em lâmina espessa alta de perfil arredondado (Fig. 5). Escrobo pouco profundo. Escapo alargado no ápice, ultrapassa a margem anterior do ocelo anterior por $0,25 \mathrm{x}$ do seu comprimento. Antena filiforme, funículos densamente pilosos (Figs. 1 e 6). Mandíbula 2.3, dente superior o maior. Sulco malar raso, com carena interna interrompida medianamente, a externa completa e contínua com a carena pós-orbital. Medidas relativas: cabeça L:A:C 55:36:35; FV 34; LS 10; EPE 7; CTE 11; EM 5; FO 15; DOA 6; APL 4; OOL 3; POL 11; olho A:L:LF 32:29:16; escapo antenal C:L 31:5; pedicelo C:L 7:5; segmentos flagelares C:L, anelo 4:4; F1,F2, F6 e F7 8:5; F3-F5 9:5; clava 15:5.

Mesossoma. Dorso do pronoto com umbílicos rasos e interstício coriáceo; laterais do pronoto com rugas horizontais que se originam da margem anterior (Fig. 7). Escultura do mesoescuto e escutelo como no dorso do pronoto, à exceção do interstício, fortemente coriáceos. Carena frenal com formato de "V". Metanoto foveado e liso. Mesopleura com acropleura costada; mesepisterno coriáceo na metade superior e acentuadamente coriáceo na inferior, faixa mediana umbilicadofoveada, carena transversal incompleta; sutura mesopleural conspícua; depressão femoral com carenas horizontais na metade superior, interstício coriáceo; mesepímero superior piloso, umbílicado-foveado; mesepímero inferior coriáceo. Metapleura pilosa, exceto na porção inferior; porção superior com fóveas pouco delimitadas, faixa mediana umbilicadofoveada e área inferior lisa e brilhante. Propódeo com cóstula anterior ausente; carena mediana bem definida, com dois pares 
de pequenas rugas laterais transversais; área submediana coriáceo-rugosa, cóstula posterior completa. Metafêmur com 13 dentes ventrais, o externo basal triangular, laminar agudo, não tão longo quanto os demais ventrais (Fig. 3), dente interno falciforme e rômbico (Fig. 4). Metatíbia com espinho apical pouco robusto não robusto e curvado (Fig.3). Medidas relativas: mesossoma C:L 70:51; mesoescuto C 29; escutelo C:L 29:27; asa C:L 175:54; SM 56; M43; PM 45; ES 6; metacoxa C 57; metafêmur C:L 60:25.

Metassoma. Gáster oval, com pilosidade látero-dorsal a partir do T2 e tufos de pêlos ventrais em cada esternito. Medidas relativas: pecíolo C:L 45:6; gáster C:L 69:40; T1 C:L 20:30.

Macho. Comprimento: 5,2-6,3mm. Semelhante à fêmea, exceto pela face inferior amarela; metacoxa preta, ápice amarelo; pecíolo amarelo, ápice marrom; escapo amarelo-escuro; escapo alongado e delgado nos 3/4 basais, ápice dilatado; face inferior convexa; metatíbia com espinho apical delgado; metacoxa alongada, afilada no ápice e base (Fig. 8); metafêmur com margem anterior mais reta com 12-14 dentes ventrais, o basal externo pequeno, triangular e agudo, de tamanho igual ao segundo (Fig. 8) e o interno, se presente, como saliência triangular e aguda.

Variações. Sulco malar com carena interna completa. Nas fêmeas: número de dentes ventrais do metafêmur entre $12 \mathrm{e}$ 16; o exemplar coletado em Ilhéus (BA) apresenta propódeo com três pares de rugas laterais, área submediana coriácea, metacoxa e metatarsos amarelos; o coletado em Morretes (PR) apresenta propódeo com cóstula anterior; o coletado em Nova Iguaçu (RJ) apresenta área paraescrobal, projeção interantenal e face inferior amarelas; o coletado em Ubatuba (SP) apresenta metacoxa com laterais externa e interna marrons os coletados em Juquitiba (SP) apresentam dente interno ligeiramente falciforme. Nos machos: o coletado em Santa Maria de Jetibá (ES) e os coletados em Salesópolis, apresentam propódeo com área submediana coriácea e alguns deles apresentam propódeo com um par de rugas laterais; os coletados em Domingos Martins (ES) apresentam propódeo com cóstula anterior interrompida junto à carena mediana ou totalmente desenvolvida; carena mediana sem pares de rugas laterais e metafêmur com dente interno indicado por uma saliência o exemplar coletado em Ribeirão Grande (SP) apresenta F1 mais longo que largo, metatíbia marrom-escura, dente basal externo do metafêmur com ápice ligeiramente rômbico pecíolo amarelo e área submediana do propódeo pequena, esculturada por rugas e fóveas.

Machos e fêmeas coletados em Santa Teresa (ES) e Domingos Martins (ES) apresentam sulco malar com carena interna e externa completas e metafêmur com 14 dentes ventrais

Distribuição. Brasil (SE, BA, ES, RJ, SP, PR).

\section{Hospedeiro. Desconhecido.}

Comentários. Esta espécie é similar a M. latidentata $\mathbf{s p .}$ nov. quanto ao aspecto geral do corpo e dela difere por apresentar: dente externo do metafêmur laminar, com formato triângular e ápice agudo (Fig. 3); dente interno alargado, alongado, com ápice rômbico e projeção interantenal proeminente, lateralmente comprimida em lâmina espessa, alta de perfil arredondado (Fig. 5).

Material examinado. 35 fêmeas e 8 machos. Holótipo, fêmea, com as etiquetas 'Estação Biológica da Boracéia, Trilha. Pilões, 23³9’07"S 4553'43,1"W, 03-06.IV.2001, Armadilha Moericke Bosque 5, (S.T.Amarante e eq.) (MZSP). Parátipos. BRASIL: Sergipe: 1 macho

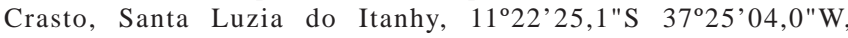
31.VIII.2001, Varredura de Vegetação (M.T.Tavares e eq.) (MZSP), Bahia: 1 fêmea Ilhéus, Mata Esperança, 1446' S 3904'W, 19.V.2002, Varredura de Vegetação (A.M.Penteado-Dias e eq.) (MZSP);1 femêa, idem, 14²6'S 3904'W, 18-21.V 2002, Arm Malaise-T6 (PenteadoDias e eq.) (UFES); Espírito Santo: 1 fêmea, Santa Teresa, Estação Biológica Santa Lúcia, 867m, 1958'39'’S 40³2'66"W, 11.IV.2001, Varredura Vegetação-pt.44 (C. O. Azevedo e eq.) (MZSP); 2 machos, Santa Maria de Jetibá, 29.XI.202 (M.T.Tavares e eq.) (UFES); 2 machos, Domingos Martins, Mata Pico do Eldorado, 20²2’17"S 40³9’29"W, 26.XI-03.XII.2004, arm. Malaise (M.T.Tavares e eq.) (UFES); Rio de Janeiro: 3 fêmeas, Nova Iguaçu, 22³4'38"S 43²6'09"W, 07.III.2002, Varredura de Vegetação (S.T.PAmarante e eq.) (MZSP); São Paulo: 3 fêmeas, Fazenda Canchim-Mata, 18.XII.1989, arm. suspensa (L.A.Joaquim) (DCBU); 1 fêmea idem, 30.VIII.1989, arm. suspensa (L.A.Joaquim) (DCBU); 5 fêmeas, Salesópolis Estação Biológica de Boracéia, 2339'01,8"S 4552'55,5"W, 04.IV.2001, Varredura de Vegetação (M.T.Tavares, e eq.) (MZSP); 1 macho, idem; 5 fêmeas, idem, 23³9'04,8"S 4553'41,8"W, 01.IV.2001, Varredura de Vegetação (M.T.Tavares e eq.) (MZSP) (material utilizado para microscopia eletrônica); 1 fêmea, Estação Biológica da Boracéia, Tr.Pilões, 2339'07"S 4553'43,1"W, 01-03.IV.2001, Armadilha Moericke (S.T.Amarante e eq.) (MZSP); 1 fêmea, idem, 2339'07"S 4553'41,8"W, 30.III-02.IV.2001, Armadilha Malaise (M.T. Tavares e eq.) (MZSP); 2 fêmeas, Juquitiba, Faz. Sonho do Vovô, 11.XI.1988, Varredura de Vegetação (L.A.Joaquim) (DCBU); 1 fêmea, idem, 12.IX.1988, idem; 1 fêmea, Ubatuba, Est. Experimental, 23.VI.1991, Armadilha Moericke (N.F.de Cristo) (DCBU); 3 machos, Ubatuba, Parque Estadual da Serra do Mar, 2301'55"S 4451'01"W, 21.I.2002, Varredura de Vegetação (N.W. Perioto e eq.) (MZSP); 1 fêmea, Ribeirão Grande, Parque Estadual de Intervales, 241' $34^{\prime \prime S} 48^{\circ} 22^{\prime} 03^{\prime \prime} \mathrm{W}$ 13.XII.2000, Varredura de Vegetação (M.T.Tavares e eq.) (MZSP) (material utilizado para microscopia eletrônica); 1 fêmea, idem, 24ำ18'16"S 48²1'53"W, 13-16.XII.2000, arm. Malaise; 1 macho, idem, 10-13.XII.2000; Paraná: 5 fêmeas, Morretes, Parque Estadual do Pau Oco, 25³4’27,5"S 4853'33,0"W, 09.IV.2002, Varredura de Vegetação (M.T. Tavares e eq.) (MZSP); 1 fêmea, idem, 25³4’27,9"S 4853'46,7"W, 11.IV.2002, Varredura de Vegetação (M.T.Tavares e eq.) (MZSP)

Melanosmicra areta (Burks, 1939)

(Figs. 10-12)

Platychacis areta Burks, 1939: 278. Costa Rica: San Mateo.

Platychalcis areta Burks: De Santis 1979: 54.

Melanosmicra areta (Burks): Delvare 1992: 185; Arias \& Delvare 2003: 137.

Descrição. Fêmea. Comprimento: 5,3-5,7 mm.

Coloração. Escapo antenal (exceto ápice), manchas do espaço paraescrobal, pernas posteriores e médias (exceto pró e mesocoxa), metade inferior da metacoxa, metatrocânter, mancha apical do metafêmur, área mediana da metatíbia, pecíolo, tarsos posteriores e tégula amarelos; ápice do escapo, pedicelo, flagelômeros, escrobo, face inferior, projeção interantenal, contorno dos dentes mandibulares, mesoescuto, 

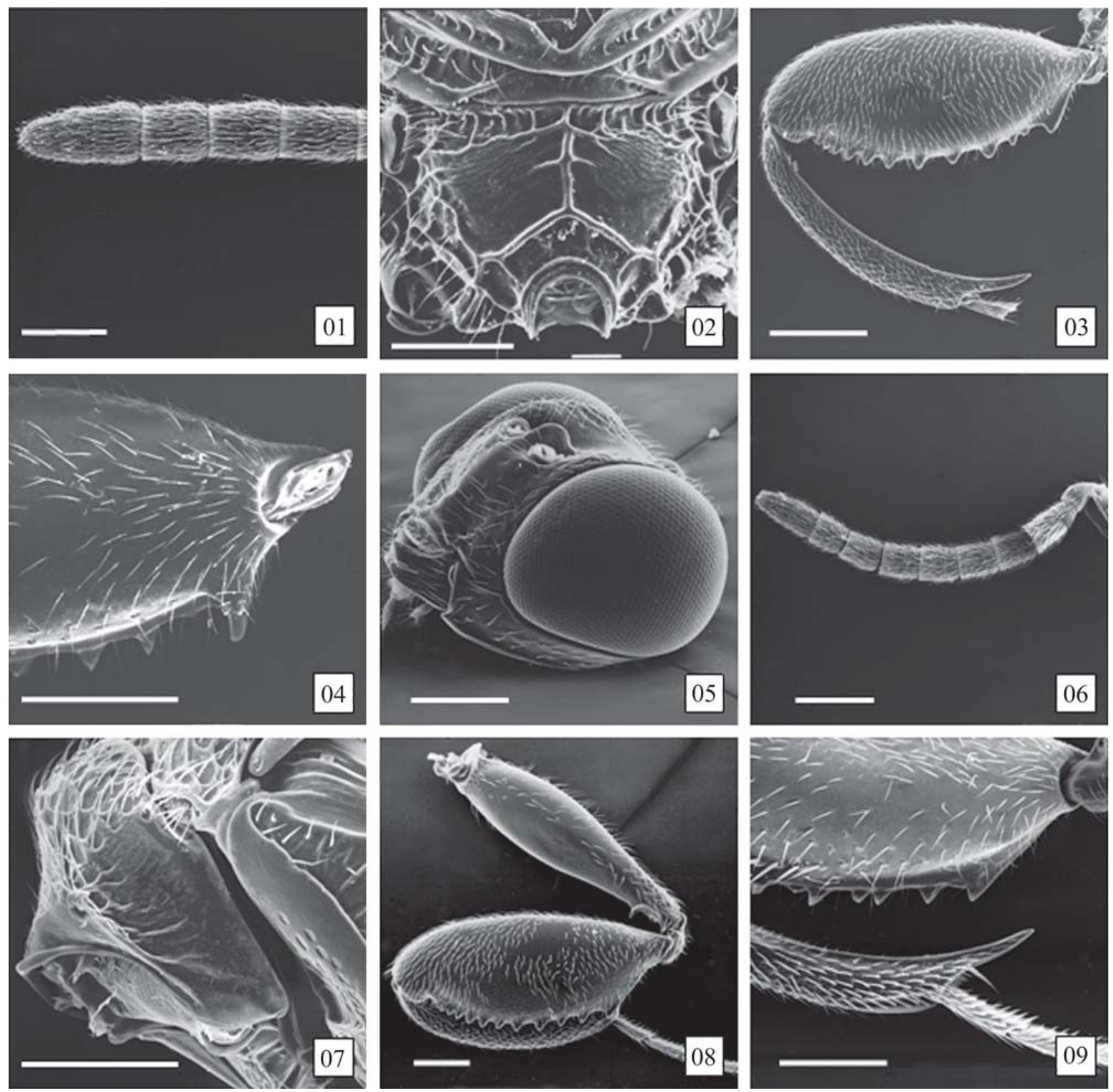

Figs. 1-9. Melanosmicra acutodentata sp. nov.: 1, ápice antena, fêmea; 2, propódeo, fêmea; 3, metafêmur e tíbia, face externa, fêmea; 4, base do metafêmur, face interna, fêmea; 5, cabeça vista lateral, macho; 6, flagelo antenal, macho; 7, mesossoma, lateral, macho; 8, perna posterior, face externa, macho; 9, base do metafêmur e ápice da tíbia, face interna, macho. Escala $0.3 \mathrm{~mm}$.

escutelo propódeo e pernas posteriores, incluindo metade basal da metacoxa, pretos; metade anterior da metacoxa, metafêmur (exceto ápice), ápice e base da metatíbia e gáster marrom-escuros; pró e mesocoxa castanhos. Asas hialinas, nervuras castanho-claras.

Cabeça. Pilosidade densa no frontovértice, espaço paraescrobal e face inferior. Superfície com umbílicos regulares e rasos no frontovértice e espaço paraescrobal, irregulares na face inferior; interstício coriáceo, inclusive no escrobo. Projeção interantenal proeminente, com base mais espessa e perfil arredondado (como na Fig. 47). Escrobo profundo. Antena filiforme, funículos densamente pilosos. Escapo ultrapassa a margem anterior do ocelo anterior por $0,25 \mathrm{x}$ o seu comprimento. Mandíbula 2.3, dente superior o maior. Sulco malar raso, com carena interna interrompida medianamente, a externa completa e contínua com a carena pós-orbital. Medidas relativas: cabeça L:A:C 63:40:36; FV 40; LS 20; EPE 7; CTE 17; EM 10; FO 20; DOA 8; APL 4; OOL 5, POL 10; OOL 5; olho A:L:LF 34:30:17; escapo antenal C:L 25:5; pedicelo C:L 5:5; segmentos flagelares C:L, anelo 4:5; F1-F6 7:7; F7 7:6; clava C:L 15:6.

Mesossoma. Dorso do pronoto com umbílicos que variam de rasos à profundos e interstício coriáceo; laterais do pronoto rugosas, com carenas horizontais anteriores. Escultura do mesoescuto e escutelo como no dorso do pronoto. Mesopleura 
com acropleura costada; mesepísterno coriáceo com faixa mediana umbilicado-foveada e carena transversal incompleta; sutura mesopleural conspícua; depressão femoral com carenas horizontais até a metade superior; mesepímero superior piloso, umbilicado-foveada, o inferior coriáceo com carenas horizontais. Metapleura pilosa, coriácea, esculturada com pontos pilíferos pequenos na área superior e central, área inferior umbilicado-foveada. Propódeo com cóstula anterior e um par de rugas laterais, que se originam da mediana, curtas; área submediana coriácea (Fig. 10). Carena frenal em formato de "V" (Fig. 10). Metanoto foveado, com ruga que delimita a depressão anterior (Fig. 10). Metafêmur com margem anterior reta, pouco estreitado na margem anterior, com 14 dentes ventrais (Fig. 11), o basal externo arredondado e acentuadamente laminar (Fig. 11), o interno bem desenvolvido, triangular, rômbico (Fig. 12). Metatíbia com espinho apical robusto, não tão longo e pouco curvado (Fig. 12). Medidas relativas: mesossoma C:L 70:60; mesoescuto C 32; escutelo C:L 30:35; asa C:L 173:63; SM 70; M 32; PM 30; ES 10; metacoxa C 50; metafêmur C:L 75:35.

Metassoma. Gáster oval, com pilosidade látero-dorsal a partir de T2. Medidas relativas: pecíolo C:L 37:8; gáster C:L 69:40; T1 C:L 25:30.

Macho. Desconhecido.

Variações. Propódeo com área submediana coriáceorugosa e carena mediana sem rugas laterais ou com ruga lateral curta (Fig. 10). Metanoto com dorselo liso, sem depressão. Metafêmur com dentes externo e interno alargados (Fig. 12); dente interno ligeiramente falciforme agudo ou trapezoidal, com ou sem dentes menores associados. Um exemplar proveniente de Sucumbios (Equador) e um de Ubatuba (SP) com pecíolo amarelo, escapo, pernas (exceto ápice inferior do metafêmur) e gáster marrom-avermelhado. Proporções comprimento/largura: F6 e F7 subquadrados. Anelo 0,6-1,0x mais longo que largo; F1-F2 1,1-1,8x; F3 1,0-2,0x; F4-F5 1,01,6x; F7 1,0-1,5x e clava 1,4-3,0x mais longos que largos; pecíolo $3,9-6,2 \mathrm{x}$ mais longo que largo; perna posterior: coxa $1,5-1,8 \mathrm{x}$ mais longa que larga; fêmur 2,0-2,2x mais longo que largo.

Distribuição.Costa Rica (San Mateo), Equador (Sucumbios), Brasil (PA, SP).

\section{Hospedeiro. Desconhecido.}

Comentários. Esta espécie apresenta como características diagnósticas: metacoxa comprimida; metatíbia com espinho apical pouco curvado (Fig. 11); metafêmur com dente externo acentuadamente laminar (Fig. 11). O holótipo de M. areta foi estudado com base em micrografias produzidas pelo sistema de foco estendido, os exemplares ora estudados diferem do holótipo por apresentarem coloração da pro, meso e ápice da metacoxa amarela e metafêmur e metatíbia mesclados de amarelo e marrom.

Material examinado. 10 fêmeas. Material não-tipo: EQUADOR: Sucumbios: 1 fêmea, R. Napo, Sacha Lodge, 22 0masl, 14-24.III.1994 (Legit: Peter Hibbis) (QCAZ). BRASIL: Pará: 1 fêmea, Rio Tocantins,
Tucuruí, 9.IX.1985, arm. de Intercepção (N.Degallier) (MPEG); São Paulo: 1 fêmea São Carlos, Fazenda Canchim-Mata, 23.X.1990 (N.W.Perioto) (DCBU); 1 fêmea, idem, 07.XI.1985, Varredura de Vegetação (A.S.Soares) (DCBU); 1 fêmea, idem, 22.IX.1988, Varredura de Vegetação (L.A.Joaquim) (DCBU); 1 fêmea, idem, 16.VIII.1989, Varredura de Vegetação (L.A.Joaquim) (DCBU) (material utilizado para microscopia eletrônica); 1 fêmea, idem, 08.XII.1988, Varredura de Vegetação (L.A.Joaquim) (DCBU); 1 fêmea, Luiz Antônio, Reserva Ecológica do Jataí, 28.I.1988 Varredura de Vegetação (L.A.Joaquim) (DCBU); 1 fêmea, Ubatuba, Fazenda Experimental, 29.V.1990, arm. Moericke (N.F.de Cristo) (DCBU); 1 fêmea, idem, 26.III.1987, Varredura de Vegetação (L.A.Joaquim) (DCBU) (material utilizado para microscopia eletrônica).

\section{Melanosmicra bilobata $\mathbf{s p . ~ n o v . ~}$}

(Figs. 13-21)

Etimologia. O epíteto específico refere-se ao hipopígeo bilobado.

Descrição. Fêmea. Comprimento: 4,0-7,2mm (holótipo: 4,0mm).

Coloração. Fronto vértice, escrobo, face inferior, funículos antenais, ápice do escapo, pronoto, mesossoma, meso e metapleura, propódeo, metade anterior da metacoxa, base, ápice e dentes ventrais do metafêmur pretos; dentes mandibulares, perna anterior e média (exceto tíbias e tarsos) e metatarsos mesclados de amarelo e preto; base e área central da metatíbia e gáster marrons; base do escapo, mancha na área paraescrobal, tégula, ápice da metacoxa, área mediana do metafêmur, tíbias e tarsos anteriores e médios, ápice da metatíbia, tarsos posteriores e pecíolo amarelos. Asas hialinas, nervuras castanho-claras.

Cabeça. Pilosidade densa no frontovértice, espaço paraescrobal e face inferior. Superfície com umbílicos regulares no frontovértice e espaço paraescrobal, irregulares e rasos na face inferior; interstício fortemente coriáceo, inclusive no escrobo (Fig. 18). Projeção interantenal muito proeminente, triangular em vista frontal e arredondada acima (Fig. 18). Escrobo profundo. Antena filiforme, funículos alargados no meio (Fig. 13); escapo robusto e alargado no ápice (Fig. 13) ultrapassa a margem anterior do ocelo anterior por $0,5 \mathrm{x}$ o seu comprimento. Covas tentoriais profundas e conspícuas acima do clípeo (Fig. 18). Mandíbula 2.3, dente superior o maior. Sulco malar estreito, raso, com carenas interna e externa completas, a externa contínua com a carena pós-orbital (Fig. 18). Medidas relativas: cabeça L:A:C 44:28:34; FV 26; LS 18; EPE 6; CTE 15; EM 5; FO 16; DOA 5; APL 3; OOL 4; POL 7; olho A:L:LF 23:22:11; escapo antenal C:L 30:4; pedicelo C:L 3:3; segmentos flagelares C:L, anelo C:L 2:3; F1-F2 6:5; F3 6:4; F4-F5 5:4; F6 6:4; F7 5:4, clava 10:4.

Mesossoma. Pronoto e mesoescuto com umbílicos rasos à profundos; no escutelo interstício (Fig. 21) e lateral do pronoto fortemente coriáceos. Carena frenal em formato de $\mathrm{V}$ (Fig. 14). Metanoto foveado, dorselo com ruga em "V" delimitando depressão anterior (Fig. 21). Mesopleura com acropleura costada; mesepisterno fortemente coriáceo, com faixa mediana umbilicada, carena transversal ausente; sutura mesopleural conspícua; depressão femoral com carenas horizontais até pouco abaixo da metade superior; mesepímero 

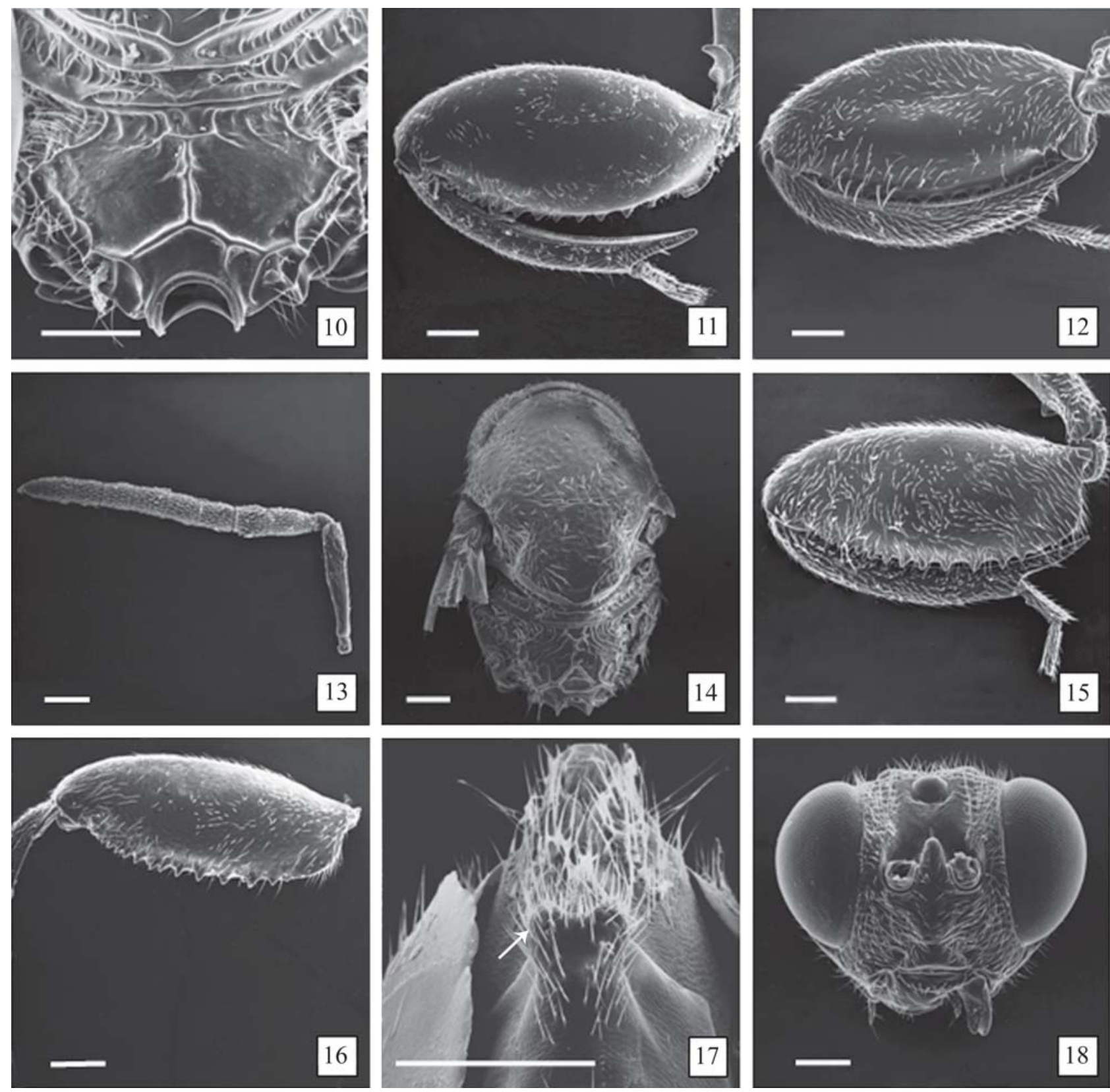

Figs. 10-18. 10-12, Melanosmicra areta (Burks), fêmea: 10, propódeo; 11, metafêmur, face externa; 12, metafêmur, face interna; 13-18, Melanosmicra bilobata sp. nov.: 13, antena, fêmea; 14, mesossoma, dorsal, fêmea; 15, metafêmur e tíbia, face externa, fêmea; 16, metafêmur, face externa, fêmea; 17, hipopígeo, fêmea, seta indicando hipopígeo bilobado; 18, cabeça, frontal, macho. Escala $0.3 \mathrm{~mm}$.

superior piloso, bastante coriáceo e umbilicado-foveado o inferior fortemente coriáceo. Metapleura pilosa, umbilicadofoveada nas áreas superior e inferior, área central com pontos pequenos. Propódeo com cóstula anterior incompleta, cóstula posterior completa; área submediana bastante coriácea. Metacoxa fina e alongada, com face externa coriácea. Metafêmur piloso, com duas fileiras de cerdas longas na margem interna inferior, margem anterior proeminente e angulosa, com 15 dentes ventrais agudos, o basal externo diminuto (Figs. 15 e 16) e o interno ausente. Metatíbia com espinho apical longo, reto e emarginado na margem anterior externa (Fig. 15). Medidas relativas: mesossoma C:L 63:45; pecíolo C:L 50:10, mesoescuto C 34; escutelo C:L 25:30; asa C:L 139:49; SM 50; M 25; PM 35; ES 5; metacoxa C 40; metafêmur C:L 51:21.

Metassoma. Gáster oval-alongado, com pilosidade láterodorsal a partir do T2; hipopígeo com ápice bilobado (Fig. 17). Medidas relativas: pecíolo C:L 31:6; gáster C:L 54:32; TIC:L 17:26.

Macho. Comprimento: 6,3-6,9mm. Semelhante à fêmea, exceto por: flagelômeros, face inferior e pecíolo mesclados de marrom e amarelo; escapo e área central da metatíbia amarelos; 
pró e mesocoxas marrom-claros; base, ápice da metatíbia e gáster marrom-escuros; flagelômeros robustos, tão longos quanto largos (Fig. 19); propódeo com carena transversal completa anterior a cóstula posterior (Fig. 21), área submediana coriáceo-rugolosa; carena frenal arredondada (Fig. 21); metafêmur alongado, com margem anterior arqueada e 18 dentes ventrais (Fig. 20); metatíbia com espinho apical curto, robusto e reto (Fig. 20); hipopígeo não bilobado.

Variações. Alguns exemplares coletados em de Ribeirão Grande (SP) apresentam coloração amarela na projeção interantenal, pedicelo, anelo, escapo antenal, perna anterior e média; coloração preta no escapo antenal, coxas e gáster; asa $3,4 \mathrm{x}$ mais longa que larga. O coletado em Bocaina (SP) apresenta coloração negra nas coxas e metaconxa $4 \mathrm{x}$ mais longa que larga. Fêmeas coletadas no Paraná e em Ribeirão Grande (SP) apresentam propódeo com carena transversal, anterior à cóstula posterior, completa como nos machos e cóstula anterior completa.

\section{Hospedeiro. Desconhecido.}

\section{Distribuição. Brasil (SP, PR).}

Comentários. Os principais caracteres diagnósticos desta espécie são: segmentos funiculares mais largos medianamente (Fig. 19); metafêmur com margem anterior arredondada (Figs. 15 e 16); metacoxa afilada; projeção interantenal muito proeminente, em vista frontal triangular e arredondada acima (Fig. 18); escapo antenal robusto e alargado no ápice (Fig. 13); pronoto, mesoescuto e escutelo com umbílicos rasos; interstícios acentuadamente coriáceos (Figs. 14 e 21); cova acima do clípeo muito profunda e conspícua (Fig. 18); face inferior coriácea (Fig. 18); espinho da metatíbia reto e muito emarginado na margem anterior externa (Fig. 20).

As fêmeas desta espécie apresentam autapomorfias como: metafêmur com margem anterior arredondada (Fig. 16) ou angulosa (Fig. 15), sem dente basal interno e hipopígeo com ápice bilobado (Fig. 17). Elas não apresentam os caracteres sinapomórficos de Melanosmicra, propostos por Delvare (1992), como: metafêmur com dente interno basal (Figs. 4, 54, 60 e 66) e espinho apical longo e curvo (Figs. 38, 43 e 50). No entanto, M. bilobata sp. nov. compartilha as sinapomorfias do clado 'Chalcis+Melanosmicra' e os caracteres diagnósticos do grupo immaculata de Melanosmicra, ambos propostos por Delvare (1992). O clado 'Chalcis+Melanosmicra' é suportado pelos seguintes caracteres: hipopígeo esclerotizado e medianamente piloso no ápice (Fig. 17). O grupo immaculata é suportado por: corpo alongado; mandíbula 2.3, dente superior maior que o inferior; projeção interantenal proeminente (Figs. 30, 40 e 62); escapo longo, que ultrapassa o vértice; mesoescuto, escutelo e propódeo umbilicados, com interstício coriáceo (Figs. 36 e 52) nunca achatados; e pecíolo longo. Tais dados dão suporte à propositura da colocação desta espécie no gênero Melanosmicra.
Material examinado. 7 fêmeas e 10 machos. Holótipo, fêmea, com a etiqueta: 'Paraná, Ponta Grossa (Vila Velha), Reserva IAPAR Br376, Levantamento Entomológico PROFAUPAR, 28.XI.1987, arm. Malaise', (DZUP). Parátipos, BRASIL: São Paulo: 1 fêmea, Ribeirão

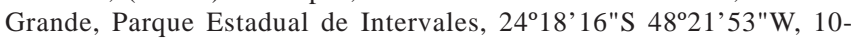
13.XII.2000, arm. Malaise (M.T.Tavares, det. 2001) (MZSP); 3 fêmeas, idem, $24^{\circ} 17^{\prime} 34^{\prime \prime S} 48^{\circ} 22^{\prime} 03^{\prime \prime W}$, 13.XII.2000, Varredura de Vegetação (M.T.Tavares e eq. col.) (MZSP) (uma das fêmeas foi utilizada para microscopia eletrônica); 1 fêmea, Serra da Bocaina, 27.X.83 (H.S.Lopes) (FIOC); Paraná: 1 fêmea, 10 machos, mesmos dados que o holótipo, com as seguintes datas: 18.II.1988 (1 fêmea) (material utilizado para microscopia eletrônica), 02.XI.1987 (3), 09.XI.1987 (3), 23.XI.1987 (3), 30.XI.1987(1) (DZUP e UFES).

\section{Melanosmicra carenata sp. nov.} (Figs. 69-71)

Etimologia. O epíteto específico refere-se à carena acima da projeção interantenal.

Descrição. Fêmea. Comprimento: 4,3 mm (holótipo: 4,3mm).

Coloração. Escapo antenal, tórulo, projeção interantenal, área paraescrobal, face inferior, labro, clípeo, mandíbula, pronoto, base e ápice do mesoescuto, perna anterior e média, metatrocânter, metacoxa, área mediana do metafêmur, metatíbia, tarsos posteriores, pecíolo e gáster amarelos; anelo, flagelômeros, frontovértice, região central e lateral do mesoescuto, escutelo, dorselo, base, ápice e dentes do metafêmur, base e ápice da metatíbia marrons. Asas hialinas, nervuras castanho-claras.

Cabeça. Pilosidade densa no frontovértice, face superior e inferior. Superfície com umbílicos regulares no frontovértice e espaço paraescrobal, irregulares e rasos na face inferior; interstício fracamente coriáceo, na face inferior quase liso; escrobo coriáceo. Projeção interantenal pouco proeminente e com lâmina translúcida no topo (Fig. 69). Escrobo profundo. Antena filiforme; funículos densamente pilosos; escapo antenal ultrapassa a margem anterior do ocelo anterior por $0,25 \mathrm{x}$ o seu comprimento. Mandíbula 2.3, dente superior o maior. Sulco malar raso; carenas interna e externa completas, a posterior contínua com a carena pós-orbital. Medidas relativas: cabeça L:A:C 50:34:30; FV 25; LS 10; EPE 5; CTE 10; EM 5; FO 15; DOA 6; APL 3; OOL 4; POL 8; olho A:L:LF 30:26:13; escapo antenal C:L 25:4; pedicelo C:L 5:4; segmentos flagelares C:L anelo C:L 3:4; FI-F5 6:5; F6-F7 5:5 e clava 12:5.

Mesossoma. Pronoto com umbílicos rasos no dorso, interstício coriáceo; laterais do pronoto fracamente rugosas. Mesoescuto e escutelo com umbílicos rasos, interstício fracamente coriáceo, escutelo com faixa mediana sem umbílicos. Carena frenal em formato de "V". Metanoto com ruga que delimita depressão anterior, laterais foveadas. Propódeo com cóstulas anterior e posterior completas, área submediana coriáceo-rugosa. Mesopleura com acropleura costada; sutura mesopleural conspícua; mesepisterno ligeiramente coriáceo, com faixa mediana umbilicado-foveada, carena transversal incompleta; depressão femoral com carenas horizontais; mesepímeros superior e inferior umbilicado-foveados (exceto na porção inferior do segundo), o primeiro, piloso. Metapleura 

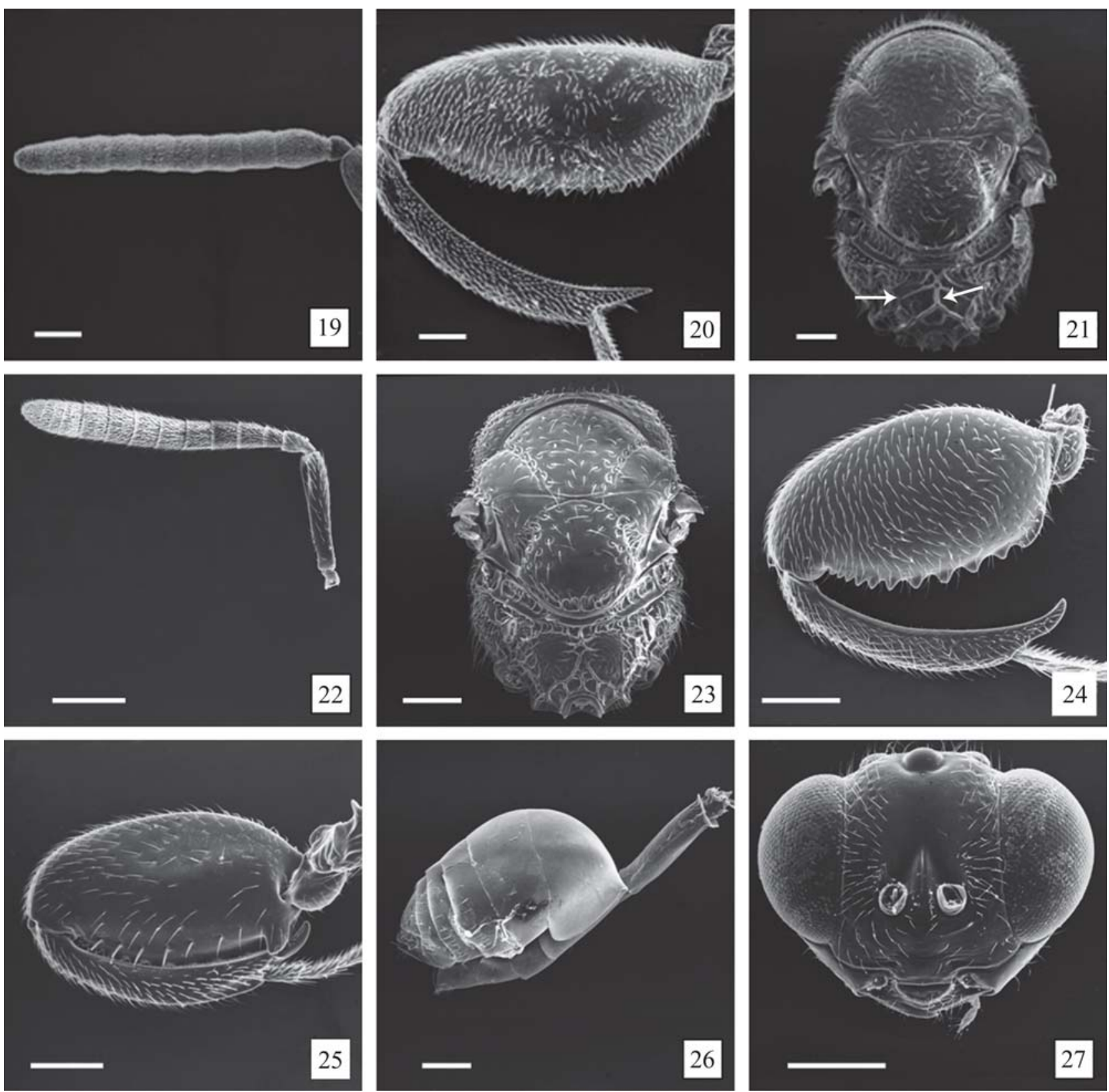

Figs. 19-27. 19-21, Melanosmicra bilobata sp. nov.: 19, flagelo antenal, macho; 20, metafêmur e tíbia, face externa, macho; 21, mesossoma dorsal, macho, propódeo, seta indicando carena transversal e cóstula anterior junto a carena mediana; 22-27, Melanosmicra flavicollis (Cameron), 22, antena macho; 23, mesossoma, dorsal, fêmea; 24, metafêmur e tíbia face externa, fêmea; 25 metafêmur e metatíbia, face interna, fêmea; 26 , metassoma, fêmea; 27, cabeça, frontal, macho. Escala $0.3 \mathrm{~mm}$.

pilosa, metade superior com pontos pilíferos e a inferior umbílicado-foveada. Metafêmur com 10 dentes ventrais, o basal externo maior, triangular, agudo e com lâmina recurvada anteriormente (Fig. 70), o interno triangular e longo (Fig. 71). Medidas relativas: mesossoma C:L 50:41; mesoescuto C 32; escutelo C:L 23:22; asa, SM 12; M 20; PM 25; ES 5; metacoxa C 47; metafêmur C:L 53:28.

Metassoma. Gáster oval, com pilosidade látero-dorsal a partir do T2. Medidas relativas: pecíolo C:L 30:6, gáster C:L 52:28; T1 C:L 15:25.
Macho. Desconhecido.

Variações. Mesoescuto e gáster marrons. Escutelo amarelo nas laterais. Propódeo com área submediana coriácea. Metafêmur com 12 dentes ventrais, dente interno alargado agudo ou em forma de gota (Fig. 71).

Distribuição. Brasil (PA, RO).

Hospedeiro. Desconhecido. 
Comentários. Esta espécie é similar à M. rugosa $\mathbf{s p . ~ n o v . ~}$ pelo padrão de coloração do corpo, pela projeção interantenal pouco proeminente e com carena no topo (Figs. 55 e 69); dela se diferencia por apresentar metafêmur mais curto; dente basal externo laminar e maior que os demais (Fig. 70), dente interno alongado, alargado agudo ou em forma de gota (Fig. 71); metapleura umbilicado-foveada na metade inferior; projeção interantenal pouco mais proeminente, com lâmina translúcida no topo; e face inferior com escultura fraca.

Material examinado. 2 fêmeas. Holótipo, fêmea, com a etiqueta 'Rondônia, Ouro Preto d'Oeste, 08-11.XI.1984, arm. suspensa, F.F.Ramos, col.' (MPEG). Parátipo. BRASIL: Pará: 1 fêmea, Paragaminas, Fazenda Cachoeira do Rio Vermelho, 18-21.I.1991, arm. suspensa (P.Tadeu) (MPEG).

\section{Melanosmicraflavicollis (Cameron, 1904)} (Figs. 22-29)

Platychalcis flavicollis Cameron, 1904: 57-58. NICARÁGUA: Chinandega.

Platychalcis phalara Burks, 1939: 277-278. COSTA RICA: San Mateo. Sinonímia proposta por Delvare (1992: 186)

Platychalcis flavicollis Cameron: De Santis, 1979: 54.

Platychalcis phalara Burks: Halstead, 1988: 193-195.

Melanosmicra flavicollis (Cameron): Delvare, 1992: 186; Arias \& Delvare, 2003: 137

Melanosmicra phalara (Burks): De Santis \& Fidalgo, 1994: 11.

Descrição. Fêmea. Comprimento: 3,3-6,7mm (lectótipo: $5,1 \mathrm{~mm})$

Coloração. Preta, exceto: tórulo, pedicelo, escapo antenal, região paraescrobal, colar pronotal, par de manchas laterais no escutelo, ápice da metacoxa e do metafêmur, tíbia e tarsos amarelos; mandíbula, labro, clípeo, tégula, pró e mesocoxa e, face inferior da metacoxa, 3/4 basal do fêmur, pecíolo e face inferior do gáster castanhos; flagelos e dorso do gáster castanhos basalmente, mais escuros em direção ao ápice . Asas hialinas, exceto por mancha escura posterior à nervura estigmal da asa anterior; nervuras castanhas.

Cabeça. Pilosidade esparsa no frontovértice, espaço paraescrobal e face inferior; superfície com umbílicos regulares e rasos no frontovértice e espaço paraescrobal; umbílicos irregulares e rasos na face inferior, com interstício inconpiscuamente coriáceo, brilhante (Fig. 27). Projeção interantenal indicada por carena inconspícua (Fig. 27). Escrobo pouco profundo. Antena clavada, inserida pouco acima do nível inferior dos olhos, funículos densamente pilosos, anelo e F1 obcônicos (Fig. 22); escapo que nunca ultrapassa a margem anterior do ocelo anterior. Mandíbula simétrica, 2.2, dente inferior mais longo que o superior. Sulco malar raso, com carena interna inconspícua próxima ao olho, a externa inconspícua próxima à fossa oral, que continua como carena pós-orbital (Fig. 27). Medidas relativas: cabeça L:A:C 62:45:32; FV 46; LS 20; EPE 5; CTE 5; EM 5; FO 10; DOA 6; APL 5; OOL 6; POL 11; olho A:L:LF: 30:28:15; escapo antenal C:L, 23:5; pedicelo 33:15; segmentos flagelares C:L, anelo 4:4; F1-F2 5:6; F3-F7 5:7; clava 12:6.

Mesossoma. Pronoto achatado, com umbílicos que variam de rasos à profundos no dorso, interstício fracamente coriáceo; lateral fracamente rugosa. Mesonoto achatado, com umbílicos esparsos, profundos menores na base, interstício coriáceo próximo à margem anterior, liso e brilhante no restante (Fig. 23). Escutelo com umbílicos mais espaçados e rasos. Carena frenal ausente. Metanoto foveado, dorselo inconspícuo (Fig. 23). Mesopleura com acropleura costada; sutura pleural conspícua; mesepisterno com metade superior lisa, a inferior umbilicada e carena transversal incompleta; depressão femoral com carenas horizontais; mesepímero superior umbilicado; mesepímero inferior carenado horizontalmente. Metapleura densamente umbilicado-foveada, umbílicos menores na porção superior. Propódeo com cóstula anterior completa em toda sua extensão; carena mediana bem definida na junção com a cóstula anterior, com ramificações curtas na metade anterior; área submediana coriácea, cóstula posterior completa. Metafêmur com 11 dentes ventrais grandes e espaçados até a região mediana, diminutos próximos ao ápice, o basal externo grande, arredondado e laminar (Fig. 24), o interno em forma de quilha (Fig. 25). Metacoxa lisa, brilhante, comprimida. Metatíbia com espinho apical longo, robusto e curvado. Medidas relativas: mesossoma C:L 73:59; mesoescuto C 67; escutelo C:L 31:35; asa C:L 165:60, SM 65, M 23, PM 30, ES 7; metacoxa C 50; metafêmur C:L 65:34.

Metassoma. Gáster ovalado (Fig. 26); T1 liso e brilhante, os demais com fileira transversal de pontos pelíferos esparsos e margem posterior coriácea (Fig. 26). Medidas relativas: pecíolo C: L 33:15; gáster C:L 70:43; T1 C:L 25:40.

Macho. Semelhante à fêmea, exceto por: mesoescuto e escutelo com umbílicos mais rasos, interstício coriáceo; o último pode apresentar coloração marrom; carena frenal reduzida; propódeo com cóstula anterior irregular nas extremidades, não definida como nas fêmeas; área submediana carenado-rugosa (Fig. 28) ou coriáceo-rugosa; metapleura pode apresentar fóveas mais rasas; metatíbia com espinho apical menos robusto e curvado; dente interno basal do metafêmur curto, triangular, com ápice agudo; dente basal externo curto, largo e arredondado no ápice; dentes ventrais como na Fig. 29.

Variações. Flagelo antenal que varia de amarelo a castanho-escuro, em alguns exemplares F1-F4 mais claros que os segmentos apicais; projeção interantenal amarela; colar pronotal mesclado de amarelo e preto a totalmente castanho; mesoescuto com duas manchas laterais amarelas; escutelo com porções escuras que variam de castanho à preto; manchas amarelas que podem coalescer medianamente ou, nos machos, escutelo todo amarelo; metatíbia mais escura ou 3/4 basais castanhos e 1/4 apical amarelo; metacoxa e metafêmur amarelos, o último eventualemente com região mediana amarela e ápice marrom ou com base e ápice amarelos região mediana castanha; pecíolo amarelo; gáster enegrecido; antenas de filiformes à clavadas. Face conspicuamente coriácea; mesonoto achatado, umbílicos pouco mais densos; interstício mais intensamente coriáceo; metapleura com umbílicos foveados grandes; metafêmur 

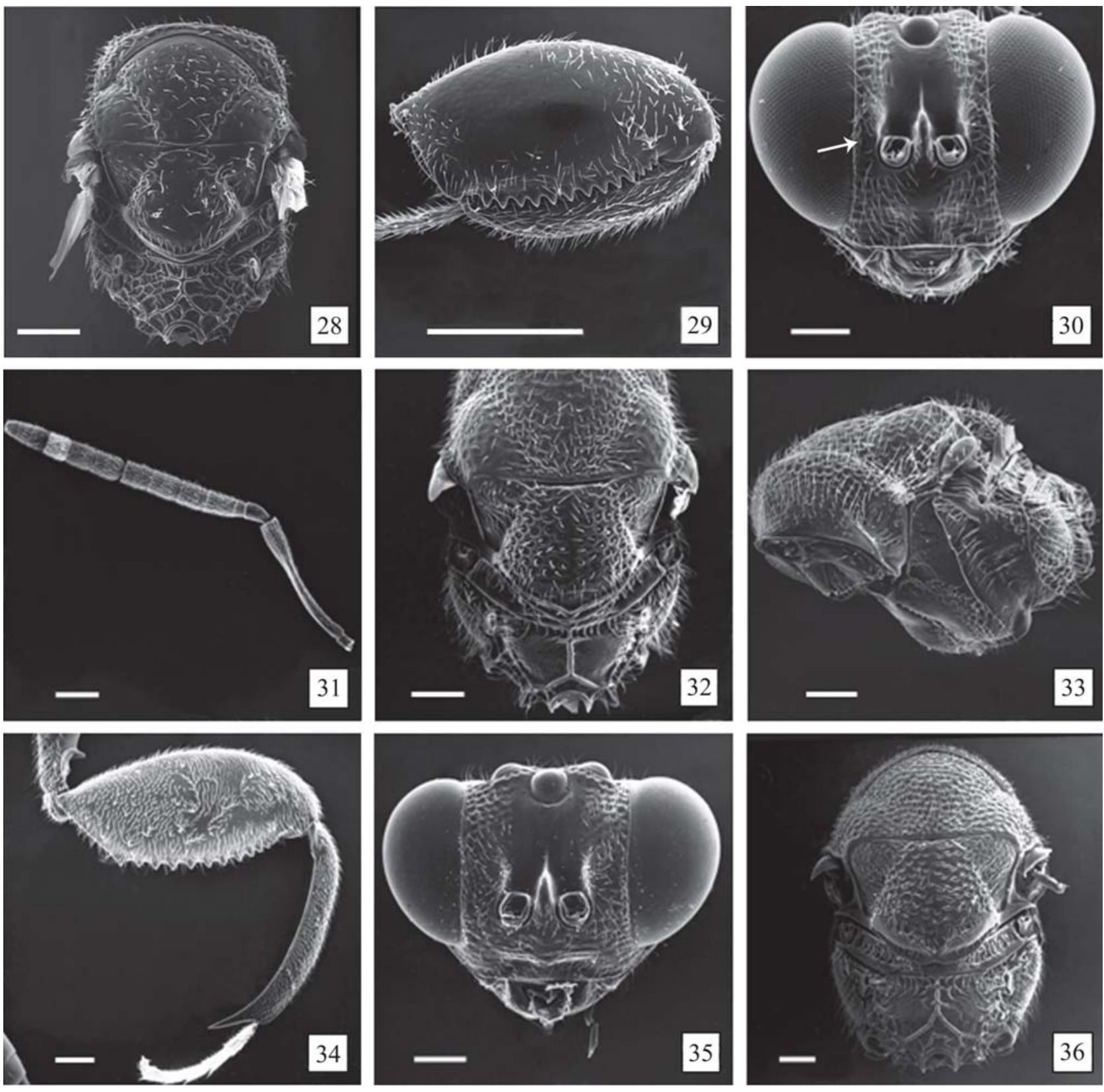

Figs. 28-36. 28-29, Melanosmicra flavicollis (Cameron), macho: 28, mesossoma, dorsal; 29, metafêmur e tíbia, face externa; 30-34, Melanosmicra gracilis (Kirby), macho: 30, cabeça, frontal, seta indicando área inferior do espaço paraescrobal proeminente; 31, antena; 32, mesossoma, dorsal; 33, mesossoma, lateral; 34, metafêmur e tíbia, face externa; 35-36, Melanosmicra guara sp. nov., fêmea: 35, cabeça, frontal; 36, mesossoma, dorsal. Escala $0.3 \mathrm{~mm}$.

com número de dentes ventrais que variam de 9-13; o dente basal interno triangular, curto, largo e agudo, em forma de quilha ou falciforme; dente basal externo de pequeno e triangular à grande e laminar. Proporções da perna posterior: coxa 1,4-1,8x mais longa que larga; fêmur 1,8-2,0x mais longo que largo.

Proporções comprimento/largura: cabeça 1,4-1,7x mais larga que alta; 1,6-2,0x mais larga que longa; olhos: olho 1,6-2,7x mais alto que sua largura frontal; escapo 4,2-6,0x mais longo que largo; pedicelo $0,8-1,6 \mathrm{x}$ mais longo que largo; anelo 0,6 1,0x; F1 0,8-1,2x; F2 0,7-1,0x; F3 0,6-1,0x; F4 0,6-0,8x; F5 0,6-

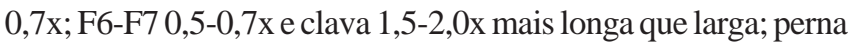

posterior: coxa 1,4-1,8x mais longa que larga; fêmur 1,8-2,0x mais longo que largo.

Distribuição. EUA (Maryland, Arizona, North Carolina, South Carolina),

México (Tamanzucale), Belize, Honduras, El Salvador (Quezaltepeque), Nicarágua, Costa Rica (Puntarenas), Panamá (Zona do Canal), Venezuela, Equador (Sucumbios), Brasil (PA*, $\left.\mathrm{AC}^{*}, \mathrm{SE}^{*}, \mathrm{RO}^{*}, \mathrm{MG}^{*}, \mathrm{ES}^{*}, \mathrm{RJ}^{*}, \mathrm{SP}^{*}, \mathrm{PR}^{*}\right)$ e Argentina.

Hospedeiro. Desconhecido. 
Comentários. Platychalcis flavicollis Cameron, 1904 foi descrita com base em fêmea da Nicarágua. Burks (1939) descreveu Platychalcis phalara com base em três fêmeas da Costa Rica e Honduras, e a diferenciou de P. flavicolis pelo pecíolo mais claro e antena filiforme. Halstead (1988) descreveu o macho de P. phalara com base em dois exemplares do México e constatou variações de coloração e de tamanho do corpo em 15 fêmeas. Delvare (1992) propôs, sem apresentar justificativas, $P$. flavicollis como sinônimo sênior de $P$. phalara. A análise do material agora estudado, cuja distribuição vai do México até o Brasil, demonstrou que coloração e formato das antenas são muito variáveis nessa espécie. As figuras de antenas de $P$. phalara e P. flavicolis apresentadas por Burks (1940) parecem ilustar os extremos de uma variação gradual. Foram também observadas variações morfológicas associadas ao tamanho dos exemplares: nos exemplares maiores, que mais se assemelham ao lectótipo de $P$. flavicollis, pode-se usualmente observar: face quase lisa (Fig. 27); antena clavada (Fig. 22); mesossoma achatado dorsalmente, com umbílicos esparsos, interstício liso e brilhante (Fig. 23); propódeo com cóstula anterior e posterior definidas, com carena mediana bem definida na base e área submediana coriácea (Fig. 23); metafêmur com dentes ventrais mais espaçados e reduzidos em número, o basal externo pequeno (Fig. 24) e o interno curto e trapezoidal. Nos exemplares de menor tamanho pode-se usualmente observar: face mais fortemente coriácea; antena tendendo a filiforme; mesoescuto e escutelo menos achatados, com umbílios menos esparsos e interstício progressivamente mais coriáceo em direção posterior; metafêmur com dentes ventrais mais numerosos e próximos entre si (Fig. 29), com os dentes basal externo e interno mais desenvolvidos; propódeo com área submediana que varia de coriácea (Fig. 23) à coriáceorugosa e rugosa (Fig. 28). Com base em tais características adotou-se, neste estudo, a sinônimia proposta por Delvare (1992).

Material examinado. 54 fêmeas e 6 machos. Tipo. Platychalcis flavicollis: Lectótipo, fêmea, com as etiquetas 'Chinandega, Nicarágua, Coll. Baker' '1425' 'Cameron Coll. 1904-313' 'Platychalcis flavicollis. Cam. Type, Nicarágua' 'BM.Type. Hym. 5.249'. Material não-tipo: MÉXICO: San Luis Potosi 1 fêmea, Tamazunchale, 23.XI.46 (E.S.Ross) (CAS); EL SALVADOR: Chiquimula: 1 fêmea, Quezaltepeque, $500 \mathrm{~m}$, 19.VI.1963 (D.Q.Cavagnaro \& M.E.Irwin.) (CAS); 1 fêmea, E. Slope Cerro Verde, 3800, 5.VII.1963, idem. COSTA RICA: Puntarenas, 1 fêmea, Golfito-United Fruit Co, 1.VII.76, arm. Malaise (M.Wasbauer) (EMEC). PANAMÁ: Panamá:1 fêmea, Amcom, Zona do Canal, 1931.VIII.37 (E.C.Van Dyke) (CAS). EQUADOR: Sucumbios, 2 fêmeas, Rio Napo, Sacha Lodge, 220mas1, 04-14.III.1994 (Peter Hibbis) (QCAZ); 1 fêmea, idem, 12-22.II.1994; 1 fêmea, idem, 14-24.III.1994. BRASIL: Pará: 1 macho, Carajás Serra Norte, 26-29.X.1994, arm. Malaise (N.Degallier) (MEPG); 1 fêmea, idem, 21.X.1984, arm. suspensa. Acre: 1 macho, Rio Branco, 25.X-8.XI.91 (F.Ramos/ A.Henriques, I.Gorayeb/N.Bittencourt), idem; Sergipe: 1 fêmea, Crasto, Santa Luzia do Itanhy, $11^{\circ} 22^{\prime} 25,3^{\prime \prime} \mathrm{S} 37^{\circ} 25^{\prime} 04,5^{\prime \prime} \mathrm{W}, 01 . \mathrm{VIII} .2001$, varredura de vegetação (M. T. Tavares) (MZSP); 1 fêmea, idem, $11^{\circ} 22^{\prime} 42,0^{\prime \prime S ~} 37^{\circ} 24^{\prime} 50,5^{\prime \prime} \mathrm{W}, 30$.VII.2001, arm. Moericke (M. T. Tavares e eq.); 1 fêmea, idem, $11^{\circ} 22$ ' $32,8^{\prime \prime} \mathrm{S} 37^{\circ} 25^{\prime} 08,0^{\prime \prime} \mathrm{W}$, 29.VII.2001; Goiás: 1 macho, Itumbiara, Fazenda da Faculdade de Agronomia-375, 08.XI.1998, arm. bacia, pasto (C.H.Marchiori) (UFES) (material utilizado para microscopia eletrônica); 1 fêmea, idem, 379, 08.XI.1998, arm. bacia-P.M.; 1 fêmea, idem, 164, 24.IV.1998,
arm.bacia-Mata (material utilizado para microscopia eletrônica); Minas Gerais: 1 fêmea, Araporã, Fazenda da Faculdade de Agronomia, 07.II.2002, arm. Malaise (C.H.Marchiori) (UFES); 1 fêmea, idem, 11.IV.2002, arm.bacia; 1 fêmea, Belo Horizonte (UFMG), Estação Ecológica, 1952'S, 4358'W-830m, 02.XII.1996, arm. Malaise (JCRFontenelle) (UFMG); Espírito Santo: Alfredo Chaves, São Francisco Batatal, 10.X.2004 (F.B.Fraga) (UFES); 1 fêmea, Linhares, Fazenda Maria Bonita, Zé Pascoal, 11-13.VIII.2000, Varredura de Vegetação (Azevedo.C.O \& Schiffer.G.) (UFES); 2 fêmeas, Cariacica, Reserva Biológica de Duas Bocas, 26.XII.1996 (Azevedo \& Santos); 1 fêmea, idem, 17.IX.1996 (Santos Sá); 1 fêmea, idem, 22.X.1997; 1 fêmea, idem, 01.V.1997; 2 fêmeas, idem, 25.III.1997; 1 fêmea, idem, 24.XI.1997; 3 fêmeas, idem, 05.XII.1996; Rio de Janeiro: 1 fêmea, Barra da Tijuca, 10.II.63 (H.S.Lopes) (FIOC); 2 fêmeas, Instituto Biológico de Entomologia Agrícola, III.1925 (Dario Mendes) (MNRJ); São Paulo: 1 macho, Ubatuba, Estação Experimental, 16.VI.1991, arm. Moericke (N.F.de Cristo) (DCBU); 1 macho, Américo Brasiliense, Cerradão Clube Naútico, 05.V.2000, Varedura Vegetação (M. T. Tavares e eq.) (UFES); 1 fêmea, Ubatuba, Estação Experimental, 08.III.1990; 1 fêmea, Ubatuba, Estação Experimental, 15.IX.1990; 1 fêmea, idem, 30.VI.1991; 1 fêmea, Bauru, UNESP-Estação Ecológica, 12.I.1994, arm. Moericke (S.S.Ruiz e eq.) (UFES); 1 fêmea, Ibitinga, Seringal, 30.XI.1988, arm. Moericke (Projeto Instituto Biológico) (IBSP); 1 fêmea, São Carlos, Fazenda Rio Cristal-Campo, 29.X-16.XI.1992, arm. Moerike (S.L.Zampieron) (DCBU); 10 fêmeas, idem, 01-05.II.1993 (material de uma das fêmeas foi utilizado para microscopia eletrônica); 1 fêmea, Jaboticabal, Fazenda Guariba, $21^{\circ} 19^{\prime} 30^{\prime \prime S} 48^{\circ} 13^{\prime} 05^{\prime \prime W}$, 0612.I.2004 (S.R.Viel) (UFES); 2 fêmeas, idem, 03-09.II.2004 (S.R.Viel) (UFES); 1 fêmea, idem, 20-26.I.2004 (S.R.Viel) (UFES); Paraná: 1 macho, Ponta Grossa (Vila Velha), Reserva IAPAR, Br 376 , Levantamento Entomológico PROFAUPAR, 28.XI.1987, arm. Malaise.

\section{Melanosmicra gracilis (Kirby, 1889)}

(Figs. 30-34)

Smicra gracilis Kirby, 1889: 143. Brasil: Theresópolis. Smicra gracilis Kirby: Dalla Torre, 1898: 377.

Sphilochalcis gracilis (Kirby): Ashmead, 1904: 418; Schmiedeknecht, 1909: 39; De Santis, 1980: 264.

Melanosmicra gracillis (Kirby, 1889): Delvare, 1992: 185.

Descrição. Macho. Comprimento: 4,8-7,3mm (lectótipo: 4,8mm).

Coloração. Região paraescrobal, projeção interantenal, face inferior (exceto região mediana e do aparato bucal), mesoescuto e escutelo; perna anterior, média (exceto pró e mesocoxa) e tarsos posteriores amarelos; pró e mesocoxa e nervuras das asas marrom-claras; antena, metatrocânter, metatíbia e metafêmur avermelhados; frontovértice, escrobo e pequena área da base do metafêmur pretos; pecíolo, gáster e metacoxa marrom-avermelhados; olhos esverdeados. Asas esfumaçadas.

Cabeça. Pilosidade densa no frontovértice, espaço paraescrobal e face inferior (exceto faixa mediana no centro da face). Umbílicos regulares no frontovértice e espaço paraescrobal, irregulares e rasos na face inferior; interstício coriáceo, inclusive no escobo (Fig. 30). Projeção interantenal proeminente, lateralmente comprimida, de perfil arredondado (Fig. 30). Escrobo profundo. Antena filiforme (Fig. 31). Face inferior quase plana (Fig. 30). Área inferior do espaço paraescrobal ligeiramente proeminente (Fig. 30). Escapo antenal alargado no ápice e ultrapassa a margem anterior do 

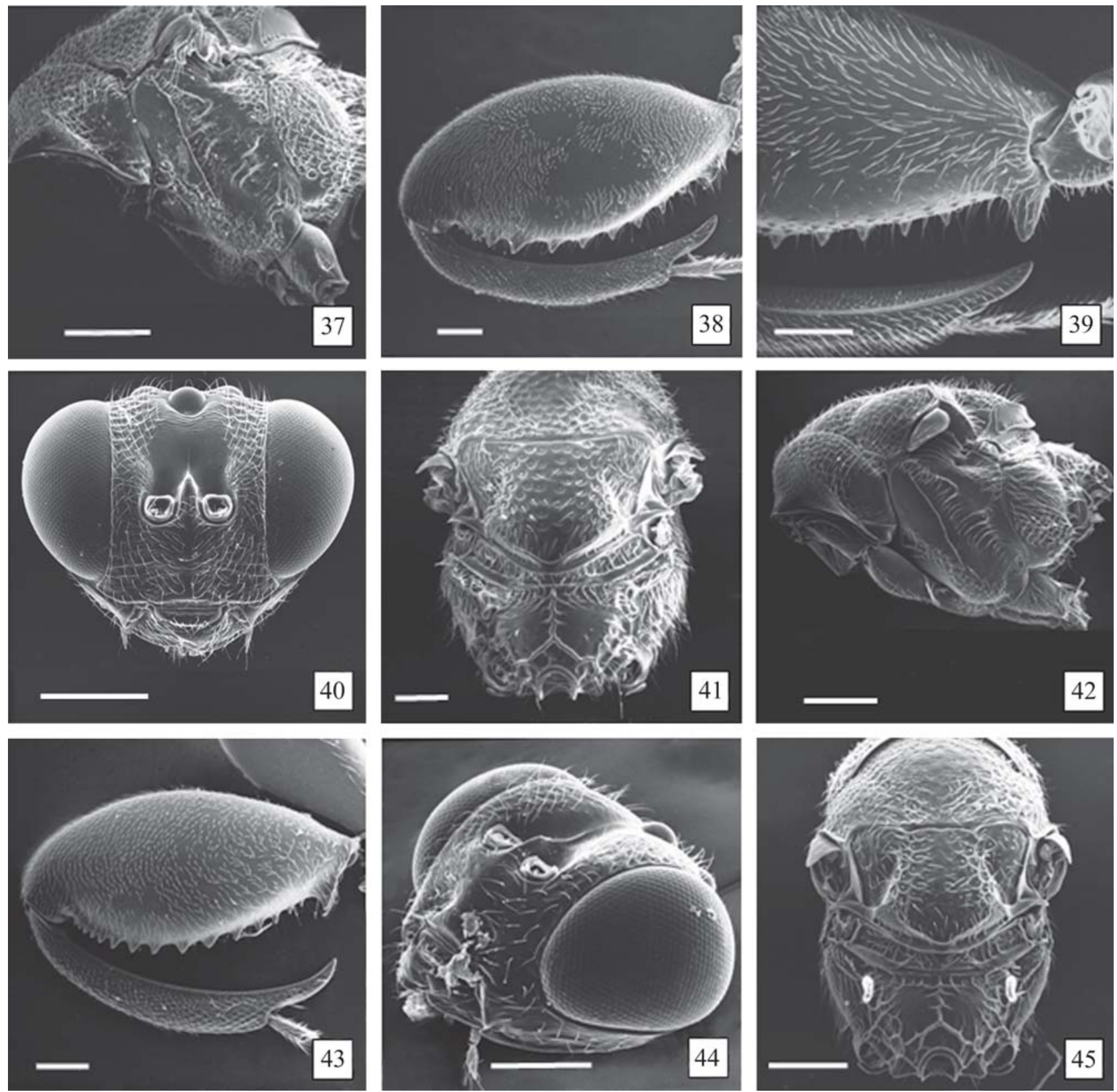

Figs. 37-45. 37-39, Melanosmicra guara sp. nov., fêmea: 37, mesossoma, lateral; 38, metafêmur e tíbia, face externa; 39, base do metafêmur e ápice da tíbia, face interna; 40-43, Melanosmicra immaculata Ashmead, fêmea: 40, cabeça, frontal; 41, mesossoma, dorsal; 42, mesossoma, lateral; 43, metafêmur, face externa; 44-45, Melanosmicra latidentata sp. nov., 44, cabeça, vista lateral, fêmea; 45, mesossoma, dorsal, fêmea. Escala $0.3 \mathrm{~mm}$.

ocelo anterior por $0,33 x$ o seu comprimento. Mandíbula 2.3, dente superior maior que o inferior. Sulco malar profundo com carenas interna e externa completas, a posterior contínua com a carena pós-orbital (Fig. 30). Medidas relativas: cabeça L:A:C 47:29:27; FV 26; LS 11; EPE 7; CTE 10; EM 5; FO 12; DOA 5; APL 5; OOL 2; POL 7; olho A:L:LF 27:26:13; escapo antenal C:L 30:3; pedicelo C:L 4:4; segmentos flagelares C:L, anelo 3:5; F1 3:3; F2 7:5; F3, F4, F6-F7 5:5; F5 6:5; clava 10:5.

Mesossoma. Dorso do pronoto umbilicado, interstício coriáceo; laterais com rugas horizontais na metade superior
(Fig. 33). Escultura do mesoescuto e escutelo como no dorso do pronoto (Fig. 32). Carena frenal ligeiramente arredondada nas laterais (Fig. 32). Dorselo e laterais do metanoto foveados (Fig. 32). Mesopleura com acropleura costada; sutura mesopleural conspícua; mesepisterno levemente coriáceo com metade inferior com faixa umbílicado-foveada e carena transversal incompleta; depressão femoral com carenas horizontais; mesepímero superior com umbilicado-foveado irregulares; mesepímero inferior rugoso (Fig.33). Metapleura pilosa com umbílicos rasos e irregulares na metade superior, 
densamente umbilicado-foveada na área inferior (Fig. 33). Propódeo, com cóstula anterior curta, carena mediana bem definida, área submediana coriácea, cóstula posterior completa (Fig. 32). Metacoxa curta, robusta, comprimida, com pilosidade látero-ventral esparsa. Metafêmur com 11 dentes ventrais grandes e espaçados, menores e próximos entre si em direção ao ápice, o externo basal diminuto, triangular agudo e semelhante ao segundo e terceiro (Fig. 34), o interno diminuto. Metatibia com espinho apical longo, delgado e pouco curvado (Fig. 34). Medidas relativas: mesossoma C:L 70:45; mesoescuto C 49 escutelo C:L 25:21; asa C:L 142:39, SM 52; M 27; PM 27; ES 5; metacoxa C 49; metafêmur C:L 60: 21.

Metassoma. Gáster, distintamente oval-alongado. Pilosidade látero-dorsal e ventral a partir de T2. Medidas relativas: pecíolo C:L 45:6; gáster C:L 56:28; T1 C:L 20:25.

\section{Fêmea. Desconhecida.}

Variações. Em um exemplar coletado em São Carlos (SP) observou-se: face inferior amarela; propódeo com área mediana de coriácea a fortemente coriácea, carena mediana com carenas tranversais curtas, pecíolo com base e ápice marrom escuros coletados em Santa Teresa (ES), metacoxa com ápice amarelo; projeção interantenal, área mediana da face inferior, flagelômeros antenais, pedicelo, ápice do pecíolo e procoxa, metatíbia, margem anterior e ápice do metafêmur pretos nos coletados em Domingos Martins (ES), metapleura com pequena área inferior coriácea; pecíolo amarelo; propódeo sem ruga lateral que se origina na carena mediana; metacoxa com ápice amarelo; metatíbia marrom-escuro (exceto por mancha amarela próxima ao ápice). Um exemplar coletado na Bolívia apresenta: projeção interantenal, pró, mesocoxa e metacoxa, manchas nos ápices da metatíbia e do metafêmur pretas; próximo ao ápice do metafêmur amarelo.

Distribuição. Brasil (ES*, RJ, SP*) Bolívia*.

Hospedeiro. Desconhecido.

Comentários. Esta espécie foi redescrita com base no lectótipo macho. Seu escapo é muito similar aos dos machos de $M$. acutodentata sp. nov. e deles difere por apresentar: flagelo mais robusto, anelo mais largo que longo (Fig. 31); projeção interantenal robusta e mais alta; porção inferior do escaço paraescrobal ligeiramente proeminente; face inferior saliente medianamente (Fig. 30); propódeo com cóstula anterior curta (Fig. 32); asa esfumaçada; metacoxa mais curta, robusta e comprimida e gáster oval alongado.

Material examinado. 7 machos. Tipo. Smicra gracillis: Lectótipo, macho, com as etiquetas 'Teresópolis, 88-137' 'Smicra gracilis' 'BMNH, Hym. Type 5-178'. Material não-tipo: BRASIL: Espírito Santo: 1 macho, Santa Teresa, Estação Biológica de Santa Lúcia, 1958’18,5"S 40³2’07,6"W, 06-09.IV.2001, arm. Malaise (C.O.Azevedo e eq.) (MZSP); 1 macho, idem, 28.III.2001, Varredura de Vegetação (Azevedo \& Kawada) (UFES) (material utilizado para microscopia eletrônica); 1 macho, Domingos Martins, Mata Pico do Eldorado, 20²2'17"S 40³9'29"W, 03-10.XII.2004, arm. Malaise
(M.T.Tavares e eq.) (UFES); 1 macho, idem, 26.XI-03.XII.2004, arm. Malaise (M.T.Tavares e eq.) (UFES); São Paulo: 1 macho, São Carlos, Fazenda Canchim-Mata, 09.XII.1989, Varredura de Vegetação (L.A.Joaquim) (DCBU) (material utilizado para microscopia eletrônica). BOLÍVIA: La Paz: 1 macho, S. Yacinto Coroico, 1700m, 5-6.XII.55, (Luis. E. Pena Gusmari) (DZUP).

\section{Melanosmicra guara sp. nov.} (Figs. 35-39)

Etimologia. O epíteto específico refere-se à semelhança da coloração castanho-avermelhada das pernas posteriores e gáster com a da pelajem do lobo-guará (Chrysocyon brachyurus) (Carnivora, Canidae).

Descrição. Fêmea. Comprimento: 6,7-8,0mm (holótipo: $7,1 \mathrm{~mm})$.

Coloração. Frontovértice, projeção interantenal, escrobo, face inferior, ápice da mandíbula, área mediana do pronoto, mesoescuto e escutelo (exceto pequena área lateral), axilas, propódeo, mesopleura, metapleura (exceto área superior), dentes ventrais do metafêmur e ápice inferior do metafêmur pretos; flagelômeros antenais, lateral do pronoto, pró e mesocoxa marrom-escuros; ocelos, área paraescrobal, pequena porção da face inferior, espaço malar, labro, clípeo, dentes mandibulares (exceto seu contorno), laterais do escutelo e mesoescuto, perna anterior e média (exceto pró e mesocoxa), tégula, pecíolo, tarsos posteriores e porção mediana da metatíbia amarelos; escapo, porção superior da metapleura, metacoxa, base e ápice da metatíbia, metafêmur e gáster castanho-avermelhados. Asas hialinas, nervuras castanhoclaras.

Cabeça. Pilosidade esparsa no frontovértice, espaço paraescrobal e face inferior. Umbílicos mais densos e regulares no espaço paraescrobal e frontovértice, menos densos e irregulares na face inferior; insterstício coriáceo, inclusive no escrobo (Fig. 35). Projeção interantenal proeminente, com base não espessa, perfil anguloso no dorso (Fig. 35). Escrobo profundo. Antena filiforme, funículos densamente pilosos; escapo longo, ultrapassa a margem anterior do ocelo anterior por $0,5 \mathrm{x}$ o seu comprimento. Mandíbula 2.3, dente superior maior que o inferior. Sulco malar profundo com carenas interna e externa completas, a posterior contínua com a carena pósorbital. Medidas relativas: cabeça L:A:C 85:52:44; FV 47; LS 30; EPE 7; CTE 15; EM 12; FO 25; DOA 8; APL 5; OOL 7; POL 16; olho A:L:LF 44:41:18; escapo antenal C:L 45:6; pedicelo C:L 19:16; segmentos flagelares C:L, anelo:10:9; F1 15:7; F2-F3 12:7; F4 12:8; F5 11:8; F6-F7 10:8 e clava 19:10.

Mesossoma. Dorso do pronoto com umbílicos densos e profundos; interstício fortemente coriáceo; laterais do pronoto acentuadamente coriáceo-rugosas, com duas carenas oblíquas na porção inferior (Fig. 37). Escultura do mesoescuto e escutelo como no dorso do pronoto (Fig. 36). Mesopleura com acropleura costada; sutura mesopleural conspícua; mesepisterno levemente coriáceo, com faixa mediana umbilicado-foveada e carena transversal incompleta; depressão femoral com carenas horizontais; mesepímero 

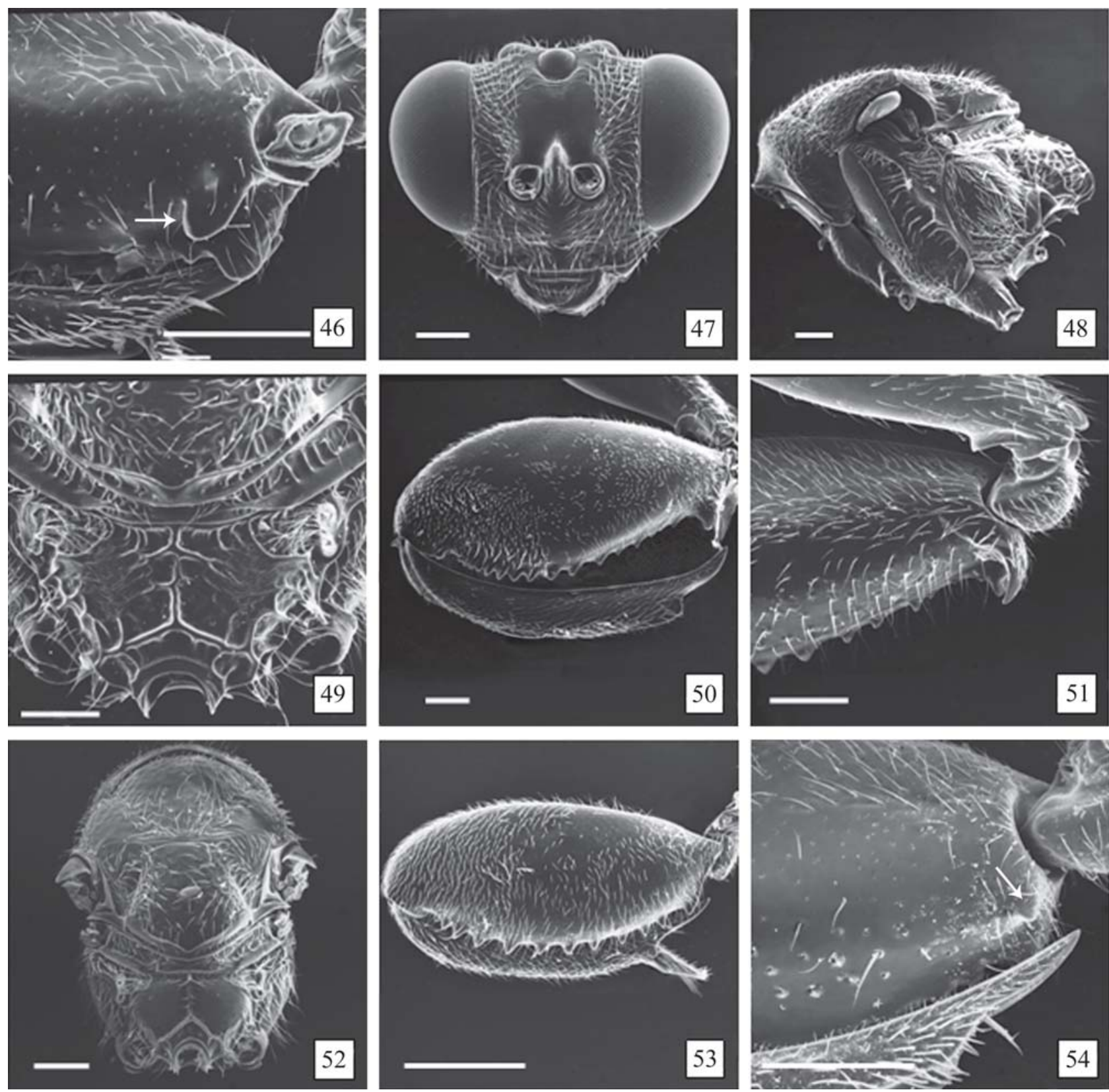

Figs. 46-54. 46, Melanosmicra latidentata sp. nov., base do metafêmur face interna, fêmea, seta indicando dente interno em formato de quilha; 47-51, Melanosmicra nigra sp. nov., fêmea: 47, cabeça, frontal; 48, mesossoma, lateral; 49, propódeo; 50, metafêmur e tíbia, face externa; 51, base metafêmur, face interna; 52-54, Melanosmicra polita sp. nov., fêmea: 52, mesossoma, dorsal; 53, metafêmur e tíbia face, externa; 54, base do metafêmur e ápice da metatíbia, face interna, seta indicando dente interno pouco desenvolvido. Escala $0.3 \mathrm{~mm}$.

superior piloso, umbilicado-foveado; mesepímero inferior coriáceo com carenas horizontais curtas (Fig. 37). Metapleura pilosa, umbilicado-foveada, exceto por pequena área inferior (Fig. 37). Carena frenal em formato de "V"(Fig. 36). Metanoto foveado, dorselo liso (Fig. 36). Propódeo com cóstula anterior incompleta, carena mediana com par de rugas laterais, cóstula posterior completa, área submediana bastante rugosa em toda sua extensão (Fig. 36). Metafêmur com 13 dentes ventrais, o basal curto e distintamente menor que o maior dente ventral (Fig. 38); dente interno falciforme e longo (como na Fig. 51).
Metatíbia com espinho apical da metatíbia recurvado (Fig. 38). Medidas relativas: mesossoma C:L 100:80; mesoescuto C 50; escutelo C:L 40:45; asa C:L 35:75; SM 85; M 45; PM 45; ES 10; metacoxa C 78; metafêmur C:L 104:49.

Metassoma. Gáster oval, liso e brilhante. Pilosidade láterodorsal e ventral a partir de T2. Medidas relativas: pecíolo C: L 45:13; gáster C:L 90:55; T1 C:L 30:50.

Macho. Desconhecido. 
Variações. Face inferior, funículos antenais, pronoto, escutelo, procoxa, metapleura e nervuras da asa pretos ou mesclados de marrom e amarelo. Propódeo de pouco à acentuadamente rugoso (Fig. 36). Metafêmur com margem anterior de pouco (Fig. 38) à muito estreitada (como na Fig. 50), 12-16 dentes ventrais, dente interno do metafêmur triangular que pode ser agudo (Fig. 39) falciforme ou bifurcado no ápice. Em exemplares coletados em Domingos Martins (ES), foram observados: escapo (exceto ápice marrom-avermelhado), tórulo, pecíolo, trocânter, região central da metatíbia e metatarsos amarelos; ápice do escapo, mancha lateral no lobo mediano do mesoescuto, mancha lateral no escutelo, perna anterior e média, área mediana e ápice da metacoxa e gáster marrom avermelhado; face superior e inferior, flagelômeros, colar pronotal, lateral do pronoto, região central do lobo mediano do mesoescuto, área mediana do escutelo, meso e metapleura, base da meso e da metacoxa e ápice do metafêmur pretos. Sulco malar com carenas interna e externa interrompidas na região central; propódeo com cóstula anterior completa e carena mediana com três pares de rugas laterais. Proporções comprimento /largura: escapo 5,8-9,0x mais longo que largo; anelo $0,6-1,4 x$ mais longo que largo; F1 1,8-2,1x, F2 1,7-2,1x, F3 1,5-2,0x, F4 1,4-1,7x, F5 1,2-1,6x, F6 1,1-1,5x, F7 1,1-1,2x e clava 1,8-2,5x mais longos que largos; pecíolo 2,4-4,5x mais longo que largo; espinho apical da metatibia $3,4-5,2 \mathrm{x}$ mais longo que largo.

\section{Distribuição. Brasil (ES, SP, PR).}

\section{Hospedeiro. Desconhecido.}

Comentários. Fêmeas desta espécie são similares a $M$. immaculata por apresentarem: pernas posteriores e gáster avermelhados; escapo, perna anterior e média e pecíolo amarelos; metafêmur estreitado na margem anterior (Fig. 43), com dente basal interno falciforme e longo (Fig. 51), o externo laminar (Figs. 38 e 43). Se diferenciam de M. immaculata por apresentar: projeção interantenal com base não espessa e perfil anguloso no dorso; mesossoma preto com manchas amarelas no mesoescuto e escutelo; painel lateral do pronoto com muitas rugas conspícuas (Fig. 37); propódeo com área submediana rugosa (Fig. 36); metapleura umbilicado-foveada (Fig. 37); metafêmur com dente basal externo mais curto e maior número de dentes ventrais (Fig. 38).

Material examinado. 13 fêmeas. Holótipo, fêmea, com as etiquetas "Jundiaí do Sul, Fazenda Monte Verde, Levantamento Entomológico Profaupar, 10.XI.1986, arm. Malaise” (DZUP). Parátipos, BRASIL: Espírito Santo: 1 fêmea, Domingos Martins, Mata Pico do Eldorado, 20²2'17'S 40³9'29"W, 03-10.XII.2004, arm. Malaise (M.T.Tavares e eq.) (UFES); São Paulo: 2 fêmeas, São Carlos, Fazenda Canchim-Mata, 17.II.1989, arm. Moericke (M.T.Tavares) (DCBU); Paraná: 4 fêmeas, Jundiaí do Sul, Fazenda Monte Verde, Levantamento Entomológico Profaupar, 10.XI.1986, arm. Malaise (DZUP); 1 fêmea, idem, 03.XI.1986; 4 fêmeas (mesmos dados que holótipo), idem, 01.XII.1986 (material utilizado para microscopia eletrônica); 1 fêmea, idem, 19.I.1987 (material utilizado para microscopia eletrônica).
Melanosmicra immaculata Ashmead, 1904

(Figs. 40-43)

Melanosmicra immaculata Asmead, 1904: 448. Brasil: Chapada. Melanosmicra immaculata Ashmead: Schmiedeknecht, 1909: 43. Ceratosmicra variventris Cameron, 1913: 114-115. Guiana. Sin. nov. Ceratosmicra ashmeadi Peck, 1963: 890. Sinonímia proposta por Delvare (1992: 185).

Ceratosmicra variventris Cameron: De Santis, 1979: 54.

Ceratosmicra ashmeadi Peck: De Santis, 1980: 271.

Melanosmicra variventris (Cameron): Delvare, 1992: 185.

Descrição. Fêmea. Comprimento: 4,2-7,0mm (lectótipo: 4,2mm).

Coloração. Mancha na região paraescrobal, tórulo, clípeo, labro, mandíbula, tégula metafêmur e $2 / 3$ anteriores da metatíbia amarelo-escuros; escrobo, frontovértice, escapo antenal, pronoto, mesonoto, propódeo, dorselo, mesopleura e dentes ventrais do metafêmur pretos; face inferior, pró e mesocoxa mescladas de amarelo e preto; pedicelo, flagelômeros, projeção interantenal, espaço malar e ápice da metatíbia marrons; perna anterior (exceto procoxa), média (exceto mesocoxa) e posterior (exceto ápice da metatíbia), pecíolo e gáster avermelhados. Asas hialinas, nervuras castanhas.

Cabeça. Pilosidade densa no frontovértice, espaço parescrobal e face inferior, que apresenta saliência na região central. Superfície com umbílicos regulares no frontovértice e espaço paraescrobal; umbílicos irregulares e rasos na face inferior, interstício coriáceo, incluindo escrobo (Fig. 40). Projeção interantenal proeminente, com base mais espessa, ligeiramente projetada para frente e com perfil arredondado (Fig. 40). Escrobo profundo. Antenas filiformes, inseridas no centro da face, funículos densamente pilosos. Escapo antenal comprimido, alargado apicalmente, ultrapassa a margem anterior do ocelo anterior por $0,5 \mathrm{x}$ o seu comprimento, segmentos funículares densamente pilosos. Mandíbula 2.3, dente superior maior que os inferiores. Sulco malar profundo, com carenas interna e externa completas, a posterior contínua com a carena pós-orbital (Fig. 40). Medidas relativas: cabeça L:A:C 48:30:27; FV 30; LS 17;EPE 3; CTE 5; EM 5; FO 12; DOA 5; APL 3, OOL 3, POL 7; olho A:L:LF: 25: 23:13; escapo antenal C:L 25:4; pedicelo C:L 5:3; segmentos flagelares, C:L anelo:4:4; F1 3:3; F2-F6 6:4; F7 5:4; clava 10:5.

Mesossoma. Dorso do pronoto com umbílicos profundos e próximos entre si; interstício coriáceo; lateral do pronoto rugosa com carena oblíqua na porção inferior (Fig. 42). Escultura do mesoescuto e escutelo como no dorso do pronoto (Fig. 41); mesonoto convexo; escutelo com faixa mediana estreita lisa e brilhante (Fig. 41); carena frenal em formato "V" (Fig. 41). Metanoto foveado, dorselo liso (Fig. 41). Mesopleura com acropleura costada; sutura mesopleural conspícua; mesepisterno coriáceo com faixa mediana umbilicado-foveada e carena transversal incompleta; depressão femoral com carenas horizontais; mesepímero superior umbilicado-foveado; mesepímero inferior coriáceo, com carenas que se extendem da depressão femoral (Fig. 42). Metapleura pilosa, com metade superior inconspícuamente coriácea, com umbílicos rasos e mal definidos; a inferior com interstício coriáceo, umbilicado- 

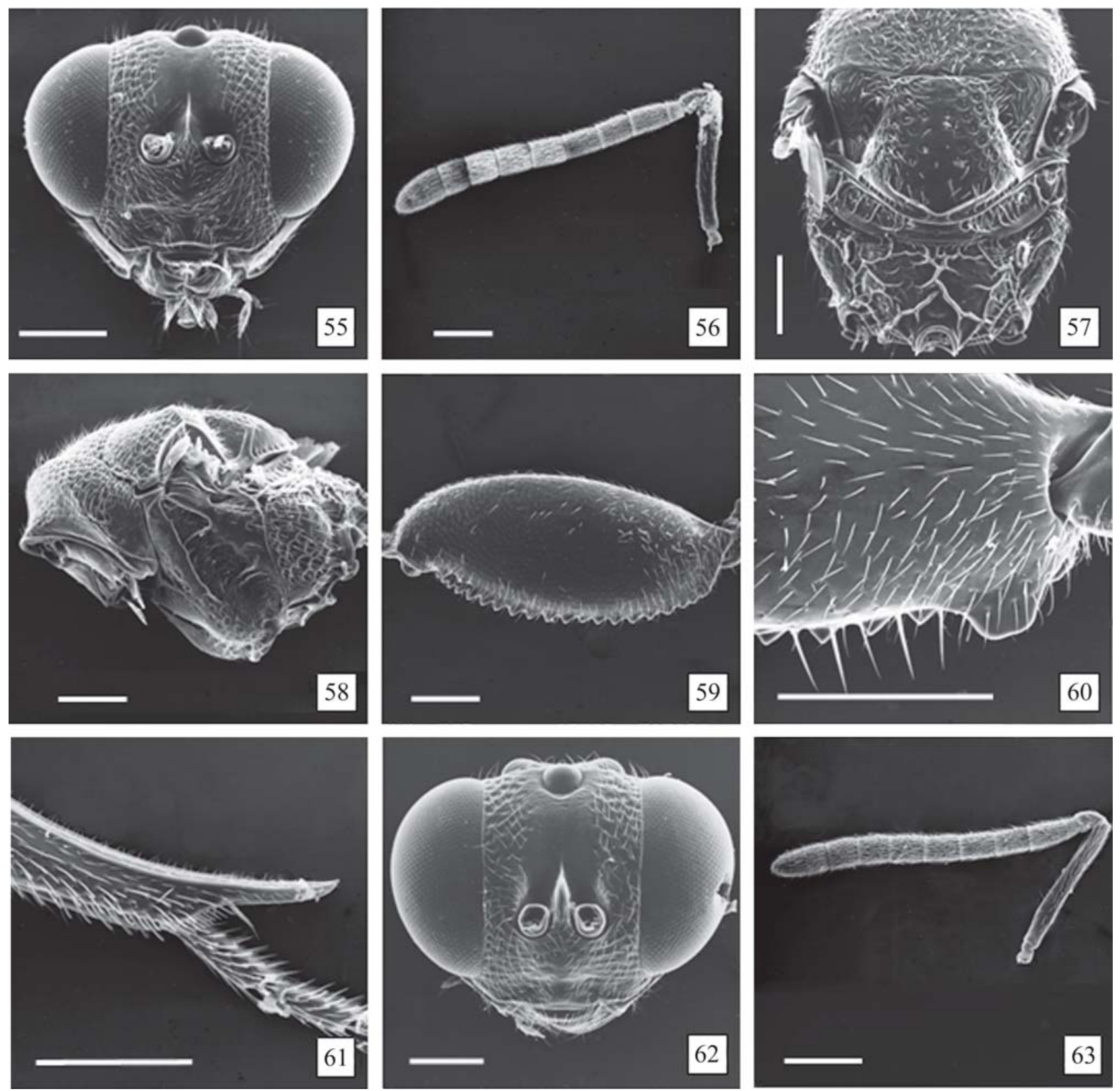

Figs. 55-63. 55-61, Melanosmicra rugosa sp. nov., fêmea: 55, cabeça, frontal; 56, antena; 57, mesossoma, dorsal; 58 mesossoma, lateral; 59, metafêmur, face externa; 60, base do metafêmur, face interna; 61, ápice da metatíbia, face interna. 62-63. Melanosmicra tricolor sp. nov., fêmea: 62, cabeça frontal; 63, antena. Escala $0.3 \mathrm{~mm}$.

foveada, exceto por pequena região coriácea inferior (Fig. 42). Propódeo com cóstula anterior interrompida próximo à carena mediana, onde se originam dois pares de rugas laterais curtas, área submediana coriácea, cóstula posterior completa (Fig. 41). Metafêmur piloso, com 15 dentes ventrais de tamanhos variados (Fig. 43), dente basal externo grande, agudo e triangular com lâmina anterior recurvada, mais longo que os demais dentes ventrais (Fig. 43), o interno acentuadamente falciforme, agudo (como na Fig. 51). Metatíbia com espinho apical acentuadamente curvado (Fig. 43). Medidas relativas: mesossoma C:L 60:41; mesoescuto C 25; escutelo C:L 24:25; asa C:L 120:47, SM 45, M 26, PM 50, ES 5; metacoxa C 41; metafêmur C:L 48:26.

Metassoma. Gáster ovalado, liso e brilhante, tergitos com faixas de pêlos espaçados à exceção de T1. Medidas relativas: pecíolo C:L 30:7; gáster C:L 44:48; T1 C:L 20:25.

Macho. Desconhecido.

Variações. Coloração geral do corpo pode ser marrom clara, exceto face, área paraescrobal, projeção interantenal, escapo, pedicelo e anelo. Metacoxa com porções basal e mediana pretas, 
a apical amarela. Metatíbia com margem anterior e ápice marromescuros, área mediana amarela. Metafêmur preto com mancha amarela no ápice. Coloração do gáster em tons de marrom que variam de claro à escuro, quase preto. Projeção interantenal de angulosa à arredondada, ligeira à acentuadamente projetada para frente. Face inferior ligeira à acentuadamente saliente na região central. Área submediana do propódeo coriáceo à coriáceo-rugosa. Espinho apical da metatibia ligeira à acentuadamente robusto e curvado. Metafêmur com margem anterior pouco à acentuadamente constricta, dente basal interno ligeiramente (como na Fig. 66) à acentuadamente falciforme (como na Fig. 51). Em alguns exemplares coletados em São Carlos (SP): F1-F7 com porção mediana mais larga (como na Fig. 19); ápice da clava mais ou menos rômbico; lateral do propódeo ligeiramente coriáceo-rugosa; carena mediana do propódo com cóstulas transversais, metafêmur com margem anterior de ligeira à acentuadamente constricta; dente basal interno do metafêmur com ápice de pouco arredondado à agudo. Nos exemplares coletados em Teresópolis (RJ): espinho apical da metatíbia acentuadamente curvo no ápice; margem anterior do metafêmur acentuadamente constricta (como na Fig. 50) e dente interno rômbico. Em alguns exemplares do sul da Mata Atlântica, coletados em S. Bento do Sul (SC) e São Francisco do Sul (SC): metatíbia com espinho apical pouco curvado; metacoxa mais roliça e metafêmur mais alongado. Parte dos exemplares coletados em Morretes (PR) apresenta: escapo amarelo (exceto ápice marrom-avermelhado); pedicelo marrom-avermelhado; flagelômeros pretos; projeção interantenal amarela e preta; pecíolo amarelo; propódeo sem rugas laterais saindo da carena mediana; pró e mesocoxa amarelas; metade ou 2/3 anteriores da metatíbia marromavermelhados, área periapical amarela e apical preta.

Distribuição. Costa Rica, Colômbia, Guiana, Equador, Brasil (AM*, BA*, MT, GO*, ES*, RJ*, SP*, $\left.\mathrm{PR}^{*}, \mathrm{SC}^{*}\right)$, Argentina*.

\section{Hospedeiro. Desconhecido.}

Comentários. As variações morfológicas acima descritas são graduais entre seus extremos, e caracterizão variações intra-específicas. Os lectótipos de $M$. immaculata e $M$. variventris foram estudados (o primeiro com base em micrografias produzidas por sistema de foco estendido) e, sem dúvida, se referem a este táxon com suas variações morfológicas, o que sustenta a propositura da sinonímia. Esta espécie é semelhante à $M$. nigra sp. nov. pela presença de: projeção interantenal proeminente, com base mais espessa e perfil arredondado; pontuação do mesoescuto e escutelo densa e profunda (Fig. 41); propódeo com área submediana coriácea (Fig. 41); escutelo com faixa mediana lisa e brilhante (Fig. 41); metapleura muito pilosa e, em grande parte não umbilicado-foveada (Figs 42 e 48) e metafêmur constricto na margem anterior (Fig. 50), dente interno basal falciforme e longo (Fig. 51). Dela difere por apresentar: lateral do pronoto menos coriáceo-rugoso e com menor número de rugas conspícuas, delimitando a lâmina que recobre a base da procoxa (Fig. 42); metapleura na metade anterior (Fig. 42) mais coriácea e na metade inferior umbilicado-foveada, com fóveas mal definidas; metafêmur com dente basal externo curto, laminar e agudo (Fig. 43).

Material examinado. 50 fêmeas. Tipos. Melanosmicra immaculata: Lectótipo, fêmea, com as etiquetas 'Melanosmicra immaculata Ashmead, fêmea, type' 'Chapada' 'H.H. Smith Coll' 'USNM TYPE No. 60, 488'. Ceratosmicra variventris: Lectótipo, fêmea, 'P. Cameron, col. 1914-110', 'Ceratosmicra ? variventris Cameron', 'Type Br. Guyana', 'BMNH, Hym. Type 5-222'. Material não-tipo: COSTA RICA: Puntarenas: 1 fêmea, Golfito-United Fruit, 1.VII.1976, arm. Malaise (M.Wasbauer) (EMEC); COLÔMBIA: 1 fêmea, Albânia, 200 m, 1955 (MNRJ), EQUADOR: Sucumbios: 3 fêmeas, Rio Napo, Sacha Lodge, 22Omasl, 24.III-03.IV.1994 (Peter Hibbs) (QCAZ); 1 fêmea, idem, 14-24.III.1994 (QCAZ); 1 fêmea, idem, 04-14.III.1994; BRASIL: Amazonas: 1 fêmea, Manaus, Campus (DCMB), 31.VIII.1979, arm. Malaise, (J.A.Rafael) (INPA); 1 fêmea (J.C.M.Carvalho) (MNRJ); 1 fêmea, Manaus, ZF3-Km23-Res.1112, 10.IX.1986, arm. Malaise (Bert Klein) (INPA); Bahia: 1 fêmea, Porto Seguro, Estação Ecológica Pau Brasil, 16²3'17,7"S 39¹0'55,8"W, 16.V.2002, Varredura de Vegetação (C.O.Azevedo e eq.) (MZSP); Goiás: 1 fêmea, Itumbiara, Fazenda Faculdade de Agronomia, 22.II.2002, arm. Malaise (C.H.Machiori e eq.) (DCBU); Espírito Santo: 1 fêmea, Vitória, Parque Estadual Fonte Grande, 26.III.2001, Varredura de Vegetação (Azevedo \& Kawada) (UFES) 1 fêmea, idem, Cariacica, Reserva Biológica de Duas Bocas, 25.II.1997 (Azevedo \& Santos); 1 fêmea, idem, 26.IX.2005 (C.A.Azevedo e eq.); 1 fêmea, idem, Alegre, Parque Estadual Cachoeira da Fumaça, 12.X.2000 (Santos Sá); 2 fêmeas, Domingos Martins, Mata Pico do Eldorado, 20²2'17"S 40³9'29"W, 26.XI-03.XII.2004, arm. Malaise (M. T. Tavares e eq.) (UFES); Rio de Janeiro: 1 fêmea, Teresópolis, Fazenda das Palmeiras, $30 . X .2005$ (A.L.B. G.Peronti e eq.) (UFES); São Paulo: 1 fêmea, Cantareira (S.Lopes) (MNRJ); 1 fêmea, São Carlos, Fazenda Canchim-Mata, 05.II.1987, Varredura de Vegetação (L.A.Joaquim) (DCBU); 1 fêmea, idem, 08.I.1987; 2 fêmeas, idem, 09.XII.1989; 1 fêmea, idem, 16.VIII.1990; 1 fêmea, idem, 16.VIII.1990; 1 fêmea, idem, 20.X.1989, arm. suspensa; 1 fêmea, idem, 20.XI.1990; 1 fêmea, idem, 09.X.1986 (A.S.Soares); 1 fêmea, idem, Fazenda Canchim-Cerrado, 15.III.1990, arm. suspensa (N.W.Perioto); 1 fêmea, idem, 10.I.1996, arm. bacia (T.M.Guerra, Joaquim.L.) (DCBU); 1 fêmea, idem, 22.I.1996, arm. suspensa; 1 fêmea, idem, 28.XII.1995; 1 fêmea, idem, 03.I.1996; 2 fêmeas, idem, 05.II.1996; 1 fêmea, Juréia, Estação Ecológica da Juréia-Itatins, $24^{\circ} 31^{\prime} 06^{\prime \prime} \mathrm{S} 47^{\circ} 12^{\prime} 06^{\prime \prime} \mathrm{W}, 03-06 . V .2002$, arm. Malaise (N.W.Perioto e eq.) (MZSP); 1 fêmea, idem, 01-04.V.2002, arm. Moericke; 1 fêmea, Ribeirão Grande, Parque Estadual de Intervales, $24^{\circ} 18^{\prime} 16^{\prime \prime} \mathrm{S}$ 4821'53"W, 11-14.XII.2000 (M.T.Tavares e eq.) (DCBU); 1 fêmea,

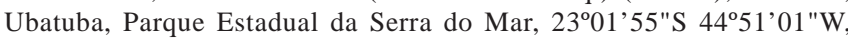
20-23.I.2002 (N.W.Perioto e eq.) (MZSP); Paraná: 1 fêmea, Morretes, Parque Estadual Pau Oco, 2534'37,2"S 4853'53,7"W, 07-10.IV.2002, arm. Malaise (M.T.Tavares e eq.) (MZSP); 2 fêmeas, idem, 0811.IV.2002, arm. Moericke (material de uma das fêmeas foi utilizado para microscopia de eletrônica); 1 fêmea Jundiaí do Sul, Fazenda Monte Verde, Levantamento Profaupar, 08.XII.1986, arm. Malaise (DZUP); 1 fêmea, idem, Telêncio Borba, Res. Samuel Klabin, 05.I.1987; 1 fêmea, Morretes, 12-19.XI.1984 (IAPAR), arm. Malaise (C.I.I.P.) (DZUP); 1 fêmea, idem, 17-24.IX.1984, (IAPAR),arm. Malaise (C.I.I.P.) (DZUP); Santa Catarina: 1 fêmea, São Bento do Sul, CEPA Rugendas, $26^{\circ}$ 19'25,6"S 49²18'26,5"W, 16-19.X.2001, arm. Moericke (A. M. Penteado-Dias e eq.) (MZSP); 1 fêmea, idem, São Francisco do Sul, CEPA Vila da Glória, 2313’40,0"S 4840’49,1"W, 17-20.X.2001, arm. Malaise (material utilizado para microscopia eletrônica); 1 fêmea, idem, arm. Moericke; ARGENTINA: 1 fêmea, Patagônia, Ariz 7-36 (E.S.Ross) (CAS).

\section{Melanosmicra latidentata sp. nov. (Figs. 44-46)}

Etimologia. O epíteto específico refere-se ao dente basal externo do metafêmur alargado. 

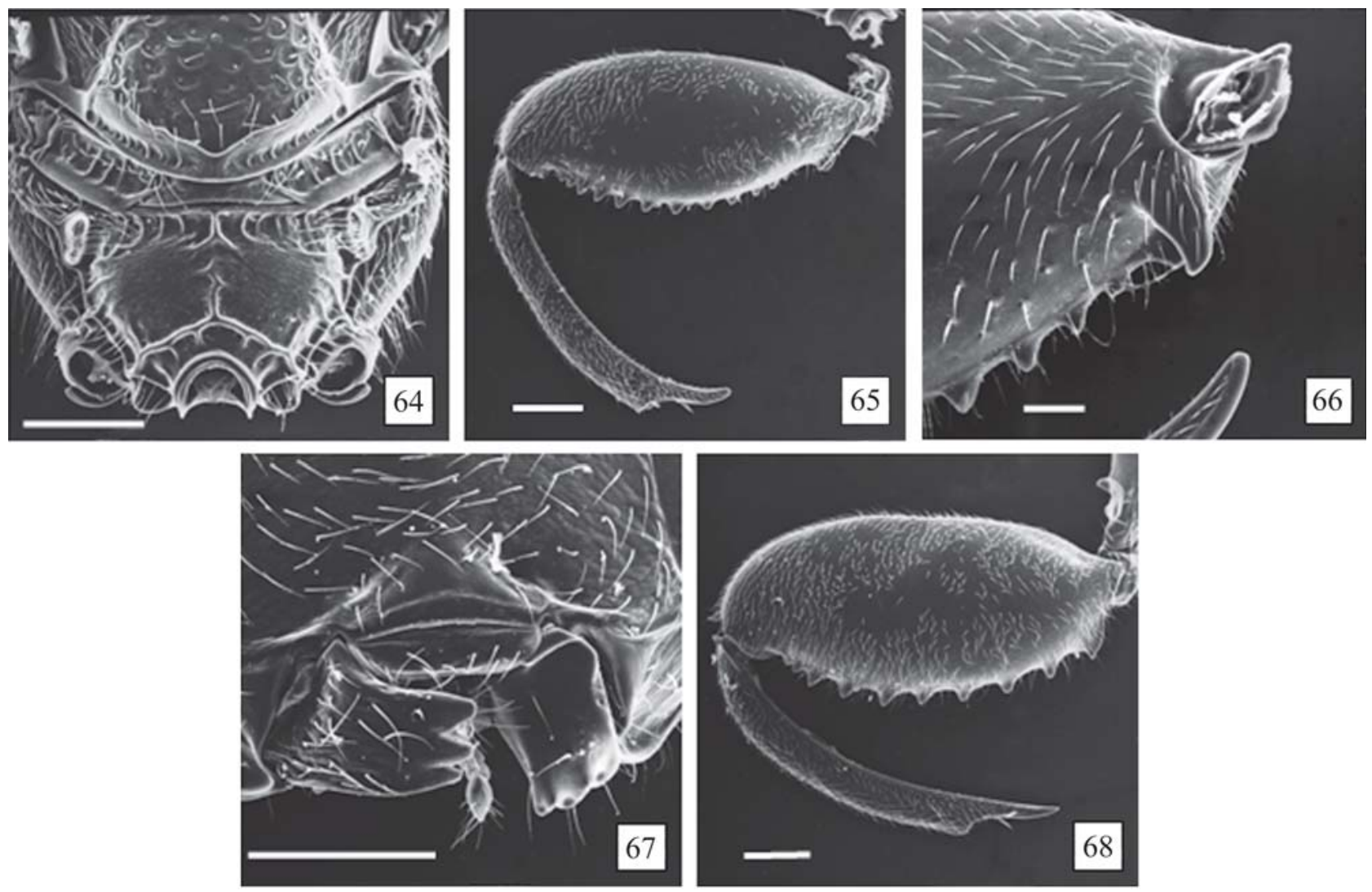

Figs. 64-68. Melanosmicra tricolor sp. nov.: 64, mesossoma dorsal, fêmea; 65, metafêmur e tíbia, face externa, fêmea; 66, base metafêmur, face interna, fêmea; 67, mandíbulas, macho; 68, base do metafêmur e tíbia, face externa, macho. Escala 0,3mm.

Descrição. Fêmea. Comprimento: 3,8-4,0mm (holótipo: $3,8 \mathrm{~mm})$.

Coloração. Escrobo, frontovértice, pronoto, mesossoma e dentes ventrais do metafêmur pretos; escapo antenal, projeção interantenal, espaço paraescrobal, face inferior, perna anterior e média, metacoxa, área mediana do metafêmur, metatíbia, tarsos posteriores e pecíolo amarelos; gáster mesclado de amarelo e marrom; flagelômeros, base e ápice do metafêmur e da metatíbia marrons. Asas hialinas, nervuras castanho-claras.

Cabeça. Pilosidade densa no frontovértice, espaço paraescrobal e face inferior. Superfície com umbílicos regulares no frontovértice e espaço paraescrobal, irregulares e rasos na face inferior; interstício coriáceo inclusive no escrobo (Fig. 44). Projeção interantenal proeminente, com perfil anguloso e ligeiramente projetada para frente (Fig. 44). Escrobo pouco profundo. Antena filiforme, funículos densamente pilosos; escapo ultrapassa a margem anterior do ocelo anterior por 0,25x o seu comprimento. Mandíbula 2.3, dente superior o maior. Sulco malar raso; carena interna interrompida medianamente, a externa completa contínua com a carena pós-orbital. Medidas relativas: cabeça L:A:C 47:34:28; FV 32; LS 15; EPE 5; CTE 6; EM 5; FO; DOA 6; APL 4; OOL 4; POL 9; olho A:L:LF 25:23:17; escapo antenal C:L 25:4; pedicelo C:L 5:4; segmentos flagelares C:L, anelo C:L 3:4; F1-F6 7:4; F7 6:4; clava 12:4.

Mesossoma. Pronoto, mesoescuto e escutelo com umbílicos rasos e interstício coriáceo (Fig. 45); o primeiro com laterais rugosas. Carena frenal em formato de "V" (Fig.45). Metanoto foveado, dorselo com rugas que delimitam uma depressão anterior (Fig. 45). Mesopleura com acropleura costada; mesepisterno ligeiramente coriáceo, com área mediana umbilicada e carena transversal incompleta; sutura mesopleural conspícua; depressão femoral coriácea, com carenas horizontais na metade anterior; mesepímero superior piloso, umbilicado-foveado; mesepímero inferior ligeiramente coriáceo. Metapleura pilosa e coriácea, área superior com pontos pequenos, a inferior umbilicado-foveada. Propódeo com cóstula anterior irregular, carena mediana com dois pares de rugas laterais; cóstula posterior completa; área submediana coriácea (Fig. 45). Metafêmur com 12 dentes ventrais, os basais largos, em forma de quilha (Fig. 46), o interno menor que o externo, que apresenta lâmina anterior pouco desenvolvida. Metatíbia com espinho apical longo, curvado (Fig. 46). Medidas relativas: mesossoma C:L 63:43; mesoescuto C 23; escutelo C:L 25:25; asa C:L 63:43, SM 50; M 30; PM 40; ES 7; metacoxa C 48; metafêmur C:L 55:23.

Metassoma. Gáster oval, com pilosidade látero-dorsal a partir do T2; T5-T8 com rugosidade dorsal, restante liso. Medidas relativas: pecíolo C:L 37:5; gáster C 41:30; T1 C:L 15:29. 
Macho. Desconhecido.

Variações. Sulco malar com carena quase completa. Área submediana do propódeo com três pares de rugas curtas laterais. Dorselo liso. Metacoxa com metade superior marrom. Metatíbia marrom no ápice.

\section{Distribuição. Brasil (RO, RJ, SP).}

\section{Hospedeiro. Desconhecido.}

Comentários. Esta espécie, embora similar a $M$. acutodentata sp. nov. no aspecto geral do corpo, dela difere por apresentar: dentes basais do metafêmur em formato de quilha, o interno menor que o externo (Fig. 46); projeção interantenal proeminente com perfil anguloso e ligeiramente projetada para frente (Fig. 44) e manchas do corpo mais claras.

Material examinado. 7 fêmeas. Holótipo, fêmea, com as etiquetas: 'São Paulo, São Carlos, Mata Canchim, 16.XII.1995, arm. suspensa (T.M.Guerra, Joaquim. L. col.) (DCBU). Parátipos, BRASIL: Roraima: 1 fêmea, Ouro Preto d'Oeste; 25-28.III.1985, arm. suspensa (F.F.Ramos) (MPEG); Rio de Janeiro: 1 fêmea, Angra-E.do Rio, JussaraX 335 (L.Trav.Et. Lopes) (MNRJ); São Paulo: 2 fêmeas, São CarlosMata Canchim, 10.I.1996, arm. suspensa (T.M.Guerra, Joaquim. L.) (DCBU); 1 fêmea, idem, 03.I.1995, arm. bacia (T.M.Guerra, Joaquim.L.) (DCBU); 1 fêmea, idem, 03.I.1996, arm. suspensa (T.M.Guerra, Joaquim) (DCBU).

\section{Melanosmicra nigra sp. nov.}

(Figs. 47-51)

Etimologia. O epíteto específico refere-se à coloração do corpo.

Descrição. Fêmea. Comprimento: 6,2-7,2mm (holótipo: 7,2mm).

Coloração. Corpo predominante negro à exceção de: escapo antenal (exceto ápice), manchas na área paraescrobal, tégula, manchas nas laterais do mesoescuto e escutelo, ápice da metacoxa, metatrocânter, tarsos anteriores, médios e posteriores, área próxima ao ápice da metatíbia, ápice do metafêmur e pecíolo amarelos; pró e mesocoxa mescladas de amarelo e preto; ápice do escapo, pedicelo, flagelômeros, projeção interantenal, face superior e inferior, escrobo, frontovértice, labro, clípeo, mandíbula, mesoescuto e escutelo (exceto manchas da lateral), propódeo, área anterior da procoxa, mesocoxa, base da metacoxa, metafêmur (exceto ápice), base e ápice da metatíbia pretos e gáster marrom-escuros. Asa hialinas, nervuras castanho-claras.

Cabeça. Pilosidade densa no frontovértice, face superior e inferior. Superfície com umbílicos regulares e rasos no frontovértice e espaço paraescrobal, irregulares e mais rasos na face inferior; interstício coriáceo, inclusive no escrobo (Fig. 47). Projeção interantenal proeminente, com base mais espessa e perfil arredondado (Fig. 47). Escrobo profundo. Antena filiforme, funículos densamente pilosos, escapo ultrapassa a margem anterior do ocelo anterior por $0,5 \mathrm{x}$ o seu comprimento.
Mandíbula 2.3, dente superior o maior. Sulco malar profundo com carenas interna e externa completas, a externa contínua com a carena pós-orbital (Fig. 47). Medidas relativas: cabeça L:A:C 80:50:43; FV 47; LS 25; EPE 8; CTE 15; EM 10; FO 20; DOA 8; APL 5; OOL 7; POL 13; olho A:L:F 40:40:24; escapo antenal C:L 41:6; pedicelo C:L 14:10; segmentos flagelares C:L, anelo 7:10; F1-F4 12:7; F5 12:8; F6 11:8; F7 10:8; clava 17:8.

Mesossoma. Dorso do pronoto com umbílicos densos e profundos e interstício fortemente coriáceo; lateral do pronoto acentuadamente coriáceo-rugosa, com ruga conspícua que delimita a lâmina que recobre a base da procoxa e carena acima da lâmina paralela superior (Fig. 48). Escultura do mesoescuto e escutelo como no dorso do pronoto. Mesopleura com acropleura costada; sutura mesopleural conspícua; mesepisterno coriáceo, com faixa mediana umbilicada, carena transversal incompleta; depressão femoral com carenas horizontais em toda sua extensão; mesepímero superior piloso, umbílicado-foveado; o inferior coriáceo com carenas horizontais (Fig. 48). Metapleura coriáceo-rugosa, com pontos pilosos na porção superior e umbilicado-foveada no quarto inferior (Fig. 48). Carena frenal arredondada (Fig. 49). Metanoto foveado, dorselo com ruga em formato de "V" que delimita uma depressão anterior (Fig. 49). Propódeo com cóstula anterior curta, carena mediana com par de rugas laterais; área submediana coriácea; cóstula posterior completa (Fig. 49). Metacoxa curta, robusta, comprimida, com pilosidade láteroventral. Metafêmur bastante estreito na margem anterior, com 15 dentes ventrais, basal externo e interno longos e pareados; o externo maior que o seguinte, triangular agudo e sem lâmina anterior (Fig. 50), o interno mais desenvolvido e falciforme (Fig. 51). Metatíbia com espinho apical robusto e ápice curvado (Fig. 50). Medidas relativas: mesossoma C:L 80:75; mesoescuto C 49; escutelo C:L 36:42; asa C:L 238:74; SM 80; M 50; PM 42; ES 6; metacoxa C 75; metafêmur C:L 96:40.

Metassoma. Gáster oval-alongado, com pilosidade láterodorsal a partir de T2. Medidas relativas: pecíolo C:L 48:12, gáster C:L 100:45; T1 C:L 25:55.

Macho. Semelhante à fêmea exceto por apresentar: pró e mesocoxa castanha; metafêmur com margem anterior mais reta; dente interno triangular alargado e rômbico.

Variações. Pronoto amarelo. Escutelo com duas manchas laterais amarelas. Metafêmur com dente externo basal alargado e rômbico com 10 à 15 dentes ventrais. Carena frenal em formato de "V". Proporção comprimento/largura: escapo 5,7-9x; anelo 0,5-1,0x; F1 1,4-2,1x; F2 1,2-1,7x; F3 1,4-2,1x; F4 1,4-1,7x; F5 1,41,8x; F6 1,4-1,7x, F7 1,4-1,5x; clava 1,7-2,5x; pedicelo 1,1-2,0x.

\section{Distribuição. Brasil (AM, PA, RO, DF, PR). \\ Hospedeiro. Desconhecida.}

Comentários. Diferentemente das demais espécies do gênero, esta apresenta coloração geral do corpo negra, quase uniforme, metafêmur com margem anterior mais constrita (Fig. 50) e dentes basais externo e interno pareados. É semelhante à 
M. guara sp. nov. pela lateral do pronoto acentuadamente coriáceo-rugosa e pelas duas carenas oblíquas na porção inferior (Figs. 37 e 48).

Material examinado. 7 fêmeas e 2 machos. Holótipo, fêmea, com as etiquetas 'Jundiaí do Sul, Fazenda Monte Verde, Levantamento Entomológico Profaupar, 10.XI.1986, arm. Malaise' (DZUP). Parátipos. BRASIL: Amazonas: 1 fêmea, Manaus, ZF3-KM 23Res.1113, 16.I.1986, arm. Malaise (Bert Klein) (INPA); 1 macho, idem, Campus UFAM, 30.XII.1978, arm. Malaise (J.A.Rafael) (INPA); Pará: 1 fêmea, Oriximiná, Alcoa Mineração: Rio Trombetas, 7-25.X.82, arm. Malaise (Rafael, Binda \& Vidal CBC) (INPA); Rondônia: 1 macho, Ariquemes, Rio Ji-Paraná, 2 41N-61 52º, 28.X.1986, arm. Malaise (J.A. Rafael) (INPA); Distrito Federal: 1 fêmea, Brasília, Reserva Ecológica do Roncador, Km 0 Br 251, 29.X-05.XI.81, 3A-78-10 m (IBGE); Paraná: 1 fêmea, Guarapuava, Est. Águas de Santa Clara, Levantamento Entomológico Profaupar, 24.XII.1986, arm. Malaise (DZUP); 1 fêmea, idem, 26.I.1987, arm. Malaise (DZUP) (material utilizado para microscopia eletrônica); 1 fêmea, mesmos dados que o holótipo, 10.XI.1986, arm. Malaise (DZUP) (material utilizado para microscopia eletrônica).

\section{Melanosmicra polita $\mathbf{s p . ~ n o v . ~}$}

(Figs. 52-54)

Etimologia. O epíteto específico refere-se à área submediana do propódeo fracamente esculturada e brilhante.

Descrição. Fêmea. Comprimento 5,0-5,2mm (holótipo: $5,2 \mathrm{~mm})$.

Coloração. Escapo antenal, projeção interantenal, manchas na área paraescrobal, face inferior, dentes mandibulares, pronoto, escutelo, metade posterior do mesoescuto, propódeo, tégula, perna anterior e média, metacoxa, área mediana do metafêmur, área mediana da metatíbia, três metatarsômeros basais e pecíolo amarelos; flagelômeros, metade anterior do mesoescuto, axilas, mesopleura, área inferior da metapleura e dentes ventrais do metafêmur pretos; área apical da metapleura, base e ápice do metafêmur e gáster castanhos. Asas hialinas, nervuras castanho-claras.

Cabeça. Pilosidade densa no frontovértice, espaço paraescrobal e face inferior. Superfície com umbílicos irregulares e rasos; interstício coriáceo, inclusive no escrobo. Projeção interantenal muito proeminente, triangular em vista frontal e arredondada acima (como na Fig. 18). Escrobo profundo. Antena filiforme, funículos densamente pilosos; escapo apicalmente alargado, ultrapassa a margem anterior do ocelo anterior por 0,5x o seu comprimento; anelo obcônico. Mandíbula 2.3, dente superior o maior. Sulco malar raso, com carena interna interrompida na base, a externa completa e contínua com a carena pós-orbital. Medidas relativas: cabeça L:A:C 65:41:39; FV 37; LS 20; EPE 5; CTE 11; EM 7; FO 20; DOA 6; APL 3; OOL 3; POL 10; olho A:L:LF 36:35:18; escapo antenal C:L 40:5; segmentos flagelares C:L, anelo 4:4; F1 10:5; F2 7:5; F3-F5 8:6; F6 7:6; F7 7:6; clava C:L, 15:8.

Mesossoma. Pronoto, mesoescuto e escutelo com umbílicos rasos e interstícios coriáceos (Fig. 52), o primeiro com lateral rugosa. Carena frenal em formato de "V" (Fig. 52). Metanoto foveado, dorselo liso (Fig. 52). Mesopleura com
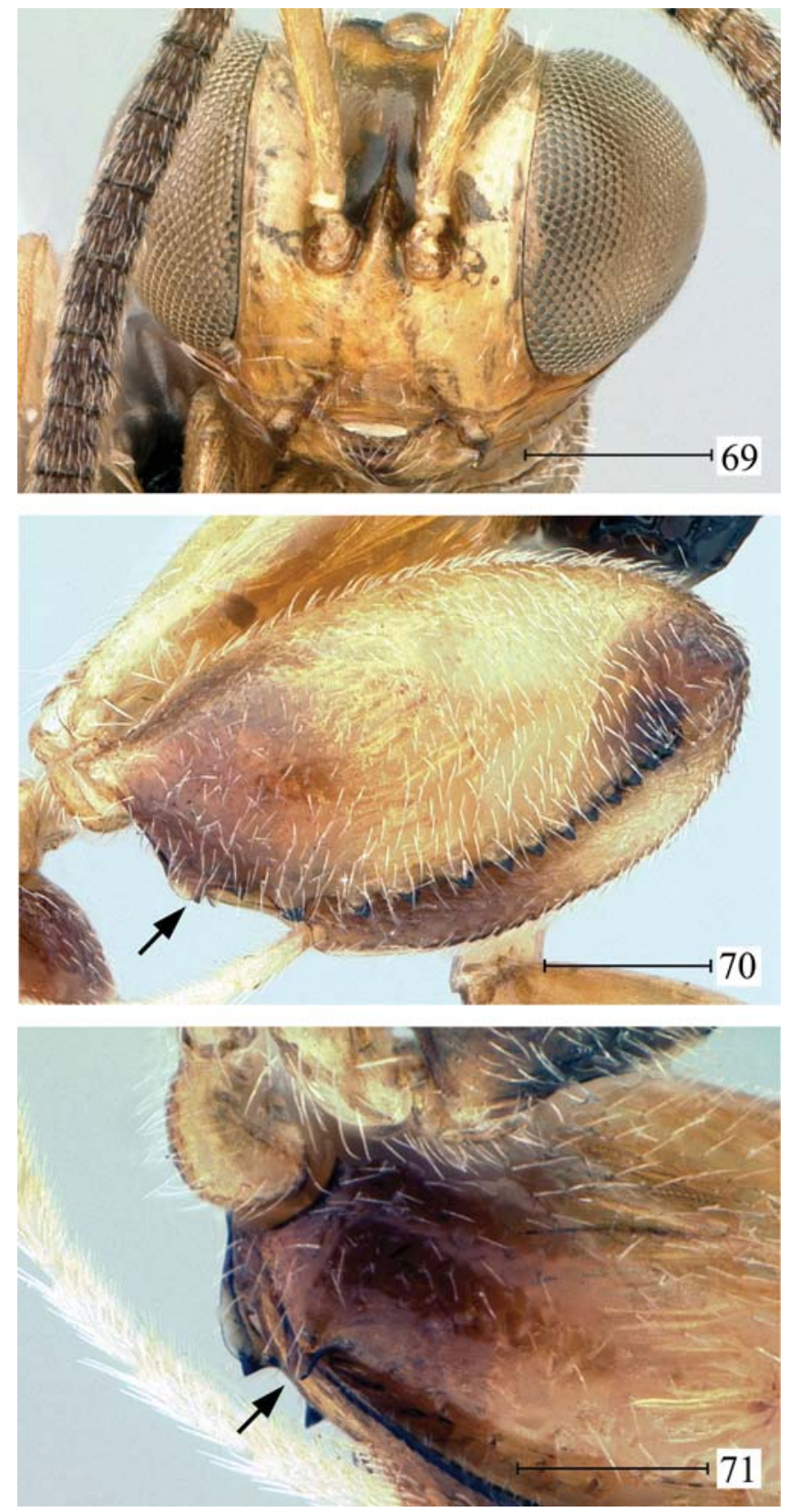

Figs. 69-71. Melanosmicra carenata sp. nov., fêmea: 69, cabeça, frontal, fêmea; 70, metafêmur (seta: dente basal externo) e tíbia, face externa; 71, base do metafêmur, (seta: dente interno), face interna. Escala $0,3 \mathrm{~mm}$.

acropleura costada; sutura mesopleural conspícua; mesepisterno fracamente coriáceo, com faixa mediana umbílicado-foveado; depressão femoral com carenas horizontais em toda extensão; mesepímero superior piloso, umbilicado-foveado; o inferior coriáceo. Metapleura pilosa, metade superior com pontos pequenos, a inferior umbilicadofoveada (exceto por pequena área coriácea). Propódeo com cóstula anterior indicada por ruga curta próxima à carena mediana; que é fraca entre as cóstulas anterior e posterior; área submediana inconspicuamente coriácea, brilhante e ampla 
cóstula posterior completa (Fig. 52). Metafêmur estreitado nas estremidades, com 11 dentes ventrais, dois últimos diminutos e próximos, o basal externo laminar (Fig. 53), o interno pouco desenvolvido, triangular e agudo (Fig. 54). Metatíbia com espinho apical longo, robusto e pouco curvado (Fig. 54). Medidas relativas: C:L 70:59; mesoescuto C 27; escutelo C:L 31:31; asa C:L 165:51; SM 60; M 40; PM 45; ES 10; metacoxa 62; metafêmur C:L 80:35

Metassoma. Gáster oval, com pilosidade látero-dorsal a partir do T2; hipopígeo densamente piloso. Medidas relativas: pecíolo C:L 47:7; gáster C:L 65:46; T1 C:L 25:35.

\section{Macho. Desconhecido.}

Variações. Mandíbula simétrica, com 3.3 dentes. Metafêmur com 12 dentes ventrais. Proporções comprimento/ largura: 6,1-7,6x mais longo que largo; pedicelo $1,6-2,4 \mathrm{x}$ mais longo que largo; anelo 0,8x; F1 1,4-1,5x; F2 1,1-2x; F3-F5 1,11,7x; F6 1,3-1,7x; F7 1,0-1,4x; clava 1,7-2,5x mais longos que largos.

\section{Distribuição. Brasil (PR).}

\section{Hospedeiro. Desconhecido.}

Comentários. Esta espécie é definida principalmente pela seguinte combinação de caracteres: dente interno do metafêmur triangular e curto (Fig. 54); propódeo com carena mediana fraca, área submediana ampla, fracamente coriácea e brilhante (Fig. 52) e metatíbia com espinho apical longo, robusto, não curvado (Fig. 54).

Material examinado. 5 fêmeas. Holótipo, fêmea, com a etiqueta: 'Paraná, Ponta Grossa (Vila Velha); Reserva Iapar Br 376, Levantamento Entomológico Profaupar, 04.I.1988, arm. Malaise' (DZUP). Parátipos, BRASIL: Paraná: 4 fêmeas, mesmos dados que holótipo, com as seguintes datas: 04.I.1988 (material utilizado para microscopia eletrônica), 11.I.1988 (material utilizado para microscopia eletrônica), 18.I.1988, 25.I.1988 (DZUP, UFES).

\section{Melanosmicra rugosa $\mathbf{s p . ~ n o v . ~}$}

(Figs. 55-61)

Etimologia. O epípeto específico refere-se à esculturação da área submediana do propódeo.

Descrição. Fêmea. Comprimento: 4,1-4,5mm.

Coloração. Escapo antenal, pedicelo, clípeo, labro, dentes mandibulares (exceto contorno), pronoto, duas manchas laterais do escutelo, perna anterior e mediana, metacoxa, metatrocânter, parte mediana do metafêmur, metatíbia, metatarso, tégula, pecíolo e metade anterior do gáster amarelos; flagelômeros antenais, frontovértice, escrobo, face superior e inferior, contorno dos dentes mandibulares, mesoescuto e escutelo, mesopleura, metapleura, propódeo, laterais da área frenal, ápice e base do metafêmur, metade posterior do gáster castanho-claros. Asas hialinas, nervuras marrons.
Cabeça. Pilosidade esparsa no frontovértice, espaço paraescrobal e face inferior. Superfície com umbílicos regulares no frontovértice e espaço paraescrobal, umbílicos irregulares e rasos na face inferior; interstício coriáceo, incluíndo escrobo, mais conspícuo na face inferior (Fig. 55). Projeção interantenal pouco proeminente e com uma carena no topo (Fig. 55). Escrobo raso. Antena filiforme, funículos densamente pilosos (Fig. 56); escapo ultrapassa a margem anterior do ocelo anterior por $0,2 \mathrm{x}$ o seu comprimento. Mandíbula 2.3, dente superior maior que o inferior. Sulco malar raso, com carenas interna e externa completas, a posterior contínua com a carena pós-orbital (Fig. 55). Medidas relativas: cabeça L:A:C 53:37:33; FV 29; LS 15; EPE 5; CTE 8; EM 6; FO; DOA 6; APL 3; OOL 3; POL 9; olho A:L:LF 30:25:13; escapo antenal C:L 29:5; pedicelo C:L 6:5; segmentos flagelares C:L, anelo 3:5; F1-F4 7:5; F5-F7 6:5; clava C:L 12:5.

Mesossoma. Dorso do pronoto com umbílicos rasos a profundos no dorso, interstício fracamente coriáceo, laterais do pronoto coriáceas com rugas anteriores fracas (Fig. 58). Mesoescuto com umbílicos rasos à profundos, interstício coriáceo (Fig. 57). Escutelo com umbílicos profunfos, interstício coriáceo (Fig. 57). Carena frenal em formato de "V" (Fig. 57). Metanoto foveado, dorselo com ruga que delimita depressão anterior (Fig. 57). Propódeo com cóstula anterior irregular, carena mediana pouco definida e irregular; cóstula posterior completa; área submediana coriáceo-rugosa, com algumas rugas que se originam da carena mediana (Fig. 57). Mesopleura com acropleura costada; mesepisterno coriáceo, com faixa mediana umbilicado-foveada e com carena transversal incompleta; sutura mesopleural conspícua; depressão femoral coriácea com carenas horizontais; mesepímero superior piloso, umbilicado-foveado, o inferior coriáceo (Fig. 58). Metapleura coriácea, na porção inferior (Fig. 58) umbilicado-foveada. Metafêmur com margem anterior reta com 19 dentes ventrais pequenos e próximos entre si (Fig. 59), o externo basal pouco desenvolvido e arredondado (Fig. 59), o interno basal trapezoidal, com ápice rômbico, maior que o externo (Fig. 60). Metatíbia com espinho apical delgado e pouco curvado (Fig. 61). Medidas relativas: mesossoma C:L 48:52; mesoescuto C 27; escutelo C:L 25:30; asa C:L 133:45; SM 45; M 25; PM 27; ES 10; metacoxa C 50; metafêmur C:L 60:26.

Metassoma. Gáster ovalado, tergitos lisos e brilhantes com pontos pilosos a partir de T2. Medidas relativas: pecíolo C:L 33:5; gáster C:L 58:36; T1 C:L 23:30.

Macho. Comprimento 4,5-5,0 mm. Semelhante à fêmea, exceto: por propódeo com área submediana rugosa-foveada; metacoxa com metade superior marrom e metade inferior amarela; metafêmur com margem anterior reta com 14 a 15 dentes ventrais, o interno curto triangular agudo.

Variações. Nas fêmeas: F1-F3 e anelo amarelos; pronoto com uma mancha escura no centro; trocânter marrom; metacoxa com uma mancha marrom na lateral externa ; metatíbia com margem anterior e ápice marrons e amarela na região central ou metade basal amarela e metade apical marrom; metafêmur com 
16-23 dentes ventrais (Fig. 59), o interno triangular largo com ápice agudo. Parte dos exemplares coletados no Paraná apresenta: face, F5-F7 e clava preta; mesossoma dorsal e lateral preto; escutelo sem manchas laterais amarelas; propódeo preto; metacoxa amarela (exceto mancha marrom próximo à base) metafêmur com margem anterior e ápice pretos; gáster mesclado de amarelo e marrom; propódeo com carena mediana bem definida.

Distribuição. Costa Rica, Panamá, Colômbia Equador, Brasil (BA*, SP*, PR*), Bolívia.

Biologia. Desconhecida.

Material examinado. 8 fêmeas e 10 machos. Holótipo, fêmea, com a etiqueta 'Bauru, UNESP-Cerrado, 08.V.1991 (M.T.Tavares)'. Material não-tipo: BRASIL: Bahia: 1 fêmea, Porto Seguro, Estação Ecológica do Pau Brasil, 16²3'17,7"S 39²10'55,8"W, 16.V.2002, Varredura de Vegetação (C.O.Azevedo e eq.) (MZSP); São Paulo: 1 fêmea, São Carlos, Fazenda Canchim-Mata, 18.XII.1989, Varredura de Vegetação (L.A.Joaquim) (DCBU); 1 fêmea, idem, 18.XII.1995, arm. bacia (T.M.Guerra, Joaquim.L.) (DCBU) (material utilizado para microscopia eletrônica); 3 machos, idem, 12.XII.1995, idem, arm. suspensa; 2 machos, idem, 21.XI.1995; 1 macho, idem, 13.XI.1995; 2 machos, idem, 28.XII.1995; Paraná:1 fêmea, Jundiaí do Sul, Fazenda Monte Verde, Levantamento Entomológico Profaupar, 24.XI.1996, arm. Malaise (DZUP); 1 fêmea, idem, 05.I.1987 (material utilizado para microscopia eletrônica); 1 fêmea, idem, 01.XII.1986; 1 macho, idem, 10.XII.1986; 1 macho, idem, 29.XII.1986; 1 fêmea, S. José dos Pinhais (Br 277-Km 54), 29.X-05.XI.1984, arm. Malaise (DZUP); 1 fêmea, Ponta Grossa (Vila-Velha), idem, 07.XII.1987.

\section{Melanosmicra tricolor sp. nov.} (Figs. 62-68)

Etimologia. O epíteto específico refere-se ao padrão de cor do corpo, mesclado de amarelo, marrom e preto.

Descrição. Fêmea. Comprimento: 4,8-6,0mm (holótipo: 6,0mm)

Coloração. Escapo, labro, clípeo, dentes mandibulares (exceto contorno), pronoto, tégula, metatrocânter, perna anteriore e média, metacoxa (exceto ápice da face lateral externa), região mediana do metafêmur e metatibia, tarsos posteriores e pecíolo amarelos; flagelômeros, manchas do espaço paraescrobal, projeção interantenal, região mediana da face inferior, manchas do mesoescuto, escutelo, área frenal, dorselo, área mediana do propódeo, base e ápice da metatíbia e gáster marrom-claros; escrobo, frontovértice, laterais da face inferior, axilas, mesopleura, metapleura, laterais do propódeo ápice da lateral externa da metacoxa e base e ápice do metafêmur pretos. Asas hialinas, nervuras castanho-claras.

Cabeça. Pilosidade densa no frontovértice, espaço paraescrobal e face inferior. Superfície com umbílicos regulares no frontovértice e espaço paraescrobal, umbílicos irregulares e rasos na face inferior; interstício coriáceo, inclusive no escrobo (Fig. 62). Projeção interantenal proeminente, com base pouco espessa e não projetada para frente (Fig. 62). Escrobo profundo. Antena filiforme com funículos densamente pilosos (Fig. 63). Escapo com ápice dilatado, ultrapassa a margem anterior do ocelo anterior por $0,2 \mathrm{x}$ o seu comprimento.
Mandíbula 2.3, dente superior o maior. Sulco malar raso, carena interna interrompida medianamente, a externa completa e contínua com a carena pós-orbital. Medidas relativas: cabeça L:A:C 67:40:38; FV 38; LS 15; EPE 5; CTE 12; EM 5; FO 15; DOA 6; APL 4; OOL 3; POL 10; OOL 3; olho A:L:LF 37:35:16; escapo antenal C:L 40:5; pedicelo C:L 6:5; segmentos flagelares C:L, anelo 5:5, F1 10:5; F2 9:5; F3 10:5; F4-F5 10:6; F6 9:7; F7 8:7; clava 15:7.

Mesossoma. Dorso do pronoto com umbílicos rasos e interstício coriáceo; laterais do pronoto com rugosidade fraca. Escultura do mesoescuto e escutelo como no dorso do pronoto. Mesopleura com acropleura costada. Mesepisterno coriáceo, com carena transversal incompleta e faixa mediana umbilicada; sutura mesopleural conspícua; depresão femoral com carenas transversais; mesepímero superior piloso, umbilicado-foveado; mesepímero inferior fortemente coriáceo. Metapleura pilosa, com pontos pilíferos delicados, exceto na área mediana umbilicado-foveada, interstício coriáceo. Carena frenal em formato"V"(Fig. 64). Metanoto foveado e liso (Fig. 64). Propódeo com cóstula anterior curta, área submediana coriácea, cóstula posterior completa (Fig. 64). Metafêmur com 13 dentes ventrais, o externo basal curto, triangular laminar, não maior que os outros demais ventrais (Fig. 65), o interno falciforme e longo (Fig. 66). Metatíbia com espinho apical longo e pouco curvado (Fig. 65). Medidas relativas: mesossoma C:L 83:59; mesoescuto C 39; escutelo C:L 30:30; asa C:L 190:65; SM 55; M 39; PM 50; ES 10; metacoxa C 65; metafêmur C:L $77: 34$.

Metasoma. Gáster oval-alongado, com pilosidade láterodorsal a partir de T2. Medidas relativas: pecíolo C:L 35:7; gáster C:L 80:47; T1 C:L 25:30.

Macho. Comprimento: 3,5mm. Semelhante à fêmea exceto pelo espaço paraescrobal, projeção interantenal e face inferior amarelas; perna anterior e média amarelo-claras; propódeo com cóstula anterior completa e área submediana menos ampla; metafêmur com margem anterior mais reta, dente basal externo menos desenvolvido; o basal interno diminuto, triangular, agudo e indicado por saliência; dentes ventrais mais espaçados e em menor número; metatíbia com espinho apical menos curvado (Fig. 68).

Variações. Fêmeas. Sulco malar com carena interna interrompida medianamente ou completa. Escutelo com faixa mediana preta. Metafêmur com 11 ou 12 dentes ventrais. Nos exemplares de coletados em Quebrângulo (AL) observou-se: mesossoma preto; metade superior da metacoxa preta e metade inferior amarela; metatíbia com margem anterior e ápice pretos; tarsos posteriores castanho-escuros; gáster mesclado de preto e amarelo; propódeo com área submediana rugosa e carena mediana com rugas laterais longas; escutelo com faixa mediana com umbílicos esparsos, interstício ligeiramente coriáceo, metatíbia com espinho apical curvado. Nos exemplares coletados em Ponta Grossa (Vila Velha) foi observado metatrocânter marrom-escuro. Nos coletados em Linhares (ES), metacoxa amarela. Proporções comprimento/largura: escapo 7,0-8,6x mais longo que largo; pedicelo 1,0-1,7x mais longo que largo; anelo 0,2-0,8x mais longo que largo; F1 1,8-2,0x; F2- 
F5 1,4-2,0x; F6-F7 1,4-1,6x; clava 2,1-2,6x mais longos que largos; pecíolo 4,8-8,6x mais longo que largo. Machos. No exemplar coletado em Jundiaí do Sul (PR) se observou axilas pretas e amarelas e metacoxa amarela. Exemplar coletado em Ponta Grossa (PR) apresenta mandíbula 3:3 (Fig. 67). Exemplar coletado em Linhares (ES) apresenta 10 dentes ventrais no metafêmur, o externo basal diminuto; metacoxa com metade superior preta e metade inferior amarela. Exemplar coletado em Domingos Martins (ES) apresenta metafêmur com dente externo triangular, agudo e não maior que os demais, dente interno indicado por saliência e 13 dentes ventrais.

\section{Distribuição. Brasil (AL, MG, ES, RJ, SP, PR).}

\section{Hospedeiro. Desconhecida.}

Comentários. Esta espécie é similar à $M$. immaculata pela presença de: cóstula anterior junto à carena mediana do propódeo, área submediana coriácea; cóstula posterior completa (Fig. 41); dente externo do metafêmur laminar (Figs. 43 e 65), e dente interno falciforme e longo (Fig. 66) e dela se diferencia pelo seguinte conjunto de caracteres: coloração geral do corpo; projeção interantenal com base pouco espessa e não projetada para frente; face inferior pouco saliente na região central (Fig. 62); propódeo com carena mediana fina e fraca; espinho apical da metatíbia fraco e pouco curvado (Figs. 65 e 68).

Material examinado. 11 fêmeas e 7 machos. Holótipo, fêmea, com a etiqueta 'Alegre, Parque Estadual Cachoeira da Fumaça, 11.X.2000, Varredura de Vegetação (Azevedo.C.O) (UFES)'. Parátipos, BRASIL: Alagoas: 1 fêmea, Quebrangulo, Reserva Biológica Pedra

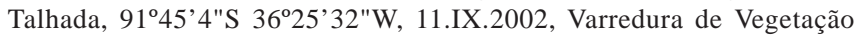
(A.M.Penteado-Dias e eq.); Minas Gerais: 1 fêmea, Belo Horizonte (UFMG) Estação Ecológica, 1952'S, 4358'W, 830m, 29.XI.1996, arm. Malaise (JCRFontenelle) (UFMG); Espírito Santo: 1 fêmea, Alegre, Parque Estadual Cachoeira da Fumaça, 12.X.2000, Varredura de Vegetação (Azevedo.C.O) (UFES); 1 macho, idem, Alegre, Parque Estadual Cachoeira da Fumaça, 11.X.2000, Varredura de Vegetação (Azevedo.C.O) (UFES); 1 macho, idem, Alegre, Parque Estadual Cachoeira da Fumaça, 12.X.2000, Varredura de Vegetação (Azevedo.C.O) (UFES); 2 machos, Linhares, R. B. Goytacazes, 06"08.X.2000, arm. Rede (Azevedo.C.O) (UFES); 1 fêmea, idem, Fazenda Maria Bonita, 12.VIII.2000, Varredura de Vegetação (Azevedo.C.O\&Schiffer.G.) (UFES) (material utilizado para microscopia eletrônica); 1 macho, Domingos Martins, Mata Pico do Eldorado, 20²2'17"S 40³9'29"W, 26.XI-03.XII.2004, arm. Malaise (M. T. Tavares e eq.) (UFES); Rio de Janeiro: 1 fêmea, Estrada Rio-SãoPaulo, Km 47, 7-12-1942 (D.Mendes); São Paulo: 3 fêmeas, São Carlos, Fazenda Canchim, 16.XII.1995, arm. suspensa (T.M.Guerra, Joaquim.L.) (DCBU) (material utilizado para microscopia eletrônica), 1 fêmea idem, 18.XII.1995, arm. suspensa (T.M.Guerra, Joaquim.L., col.) (DCBU) Paraná: 1 macho, Jundiaí do Sul, Fazenda Monte Verde, Levantamento Entomológico Profaupar, 26.I.1987, arm. Malaise (DZUP), 1 macho, Ponta Grossa (Vila Velha), Reserva IAPAR, Br 376, Levantamento Entomológico Profaupar, 21.XII.1987, arm. Malaise (DZUP) (material utilizado para microscopia eletrônica); 1 fêmea, idem, 25.V.1987 (DZUP); 1 fêmea, idem, 25.II.1988 (DZUP).
Agradecimentos. À CAPES pela bolsa concedida ao primeiro autor; Ao Dr. Alexandre Pires Aguiar e ao Dr. Nelson Wanderleiy Perioto pelas sugestões e correções, Ao Dr. Celso Oliveira Azevedo pelo auxílio na composição dos nomes específicos e sugestões. Aos técnicos do Laboratório de Microscopia Eletrônica do Departamento de Biologia Celular e Molecular e Bioagentes Patogênicos da Faculdade de Medicina de Ribeirão Preto/USP. Maria Teresa Picinoto Maglia e José Augusto Maulin pelo auxílio na preparação e confecção das micrografias de microscopia de varredura. A Andreas Taeger, C. Kutzscher (Deutsches Entomologische Institut, Eberswalde, Alemanha) e Michael Gates (Systematic Entomology Laboratory, USDA, ARS, Estados Unidos) pela confecção e envio de micrografias de material tipo. Aos dois revisores anônimos pelas correções e sugestões. Ao PROTAX (CNPq/ MCT/CAPES, proc. $n^{\circ} 563953 / 05-5$ ) e ao CNPq (procs. $n^{\circ} 620064 /$ 2006-4 e n $482629 / 2007-0)$.

\section{REFERÊNCIAS}

Arias, C. D. \& Delvare, G. 2003. Lista de los gêneros y espécies de la família Chalcididae (Hymenoptera: Chalcidoidea) de la región Neotropical). Biota Colombiana 4: 123-145.

Ashmead, W. H. 1904. Classificacion of the chalcid-flies of the superfamily Chalcidoidea, with descriptions of new species in the Carnegie Museum, collected in South America by Herbert H. Smith. Memoirs of the Carnegie Museum 1: i-xi, 225-551.

Bouček, Z. 1988. Australasian Chalcidoidea (Hymenoptera): a biosystematic revision of genera of fourteen families, with a reclassification of species. Wallingford, C.A.B. International, 1988. iii, $832 \mathrm{p}$.

Burks, B. D. 1939. Two New of Platychalcis form Costa Rica (Hymenoptera: Chalcidoidea). Arbeiten über Morphologische u. Taxonomische Entomologie 6: 275-278.

Burks, B. D. 1940. Revision of the chalcid-flies of the Tribe Chalcidini in America North of Mexico. Proceedings of the U.S. National Museum 88: 237-354.

Cameron, P. 1904. New Hymenoptera mostly from Nicaragua. Invertebrata Pacifica 1: 46-69.

Cameron, P. 1913. The Hymenoptera of the Georgetown Museum Part V. Timehri 3: 105-137.

Delvare E, G. 1992. A reclassification of the Chalcidini with a checklist of the New World species. Memoirs of the American Entomological Institute 53: 119-466.

Gibson, G. A. P. 1997. Morphology and Terminology, p. 16-44. In: Gibson, G. A. P.; J. T. Huber \& J. B. Wooley. (eds.). 1997. Annotaded Keys to the Genera of Neartic Chalcidoidea (Hymenoptera). Ottawa, National Research Council of Canada, xi+772 p.

Halstead, J. A. 1988. First records of Platychalcis in North america and new host records of Ceratosmicra spp. and Brachymeria ovata (Hymenoptera, Chalcididae). Entomological News 99: 193-198.

Harris, R. A. 1979. A glossary of surface sculpturing. Occasional Papers in Entomology 28: 1-31.

Kirby, W. F. 1889. Descriptions of new species of Tenthredinidae, Cynipidae and Chalcididae, in the collection of the British Museum. Annals and Magazine of Natural History 4: 41-144.

Noyes, J. S. 2002. Interative catalogue of World Chalcidoidea 2001. Compact Disk. Taxapad: Vancouver.

Winston, J. E. 1999. Describing species: practical taxonomic procedure for biologists. New York, Columbia University Press, $\mathrm{XX}+518 \mathrm{p}$.

Recebido em 11/10/2007; aceito em 14/10/2008 